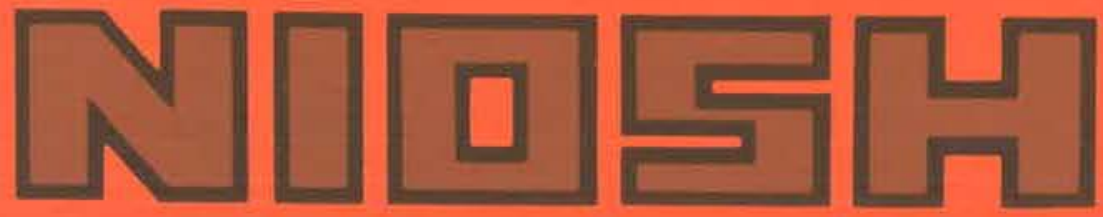

TECHNICAL INFOAMATION

\title{
SHIFT WORK PRACTICES IN THE UNITED STATES
}

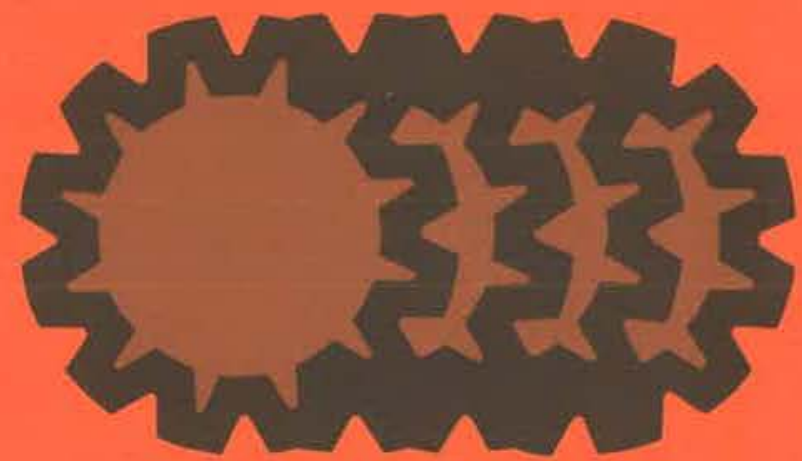

U.S.DEPARTMENT OF HEALTH, EDUCATION AND WELFARE / Public Health Service Center for Disease Control / National Institute For Occupational Sofety And Health 

SHIFT WORK PRACTICES

IN THE UNITED STATES

Donald L. Tasto

Stanford Research Institute

Michael J. Colligan

National Institute for Occupational Safety and Health

Contract No. 210-75-0072

U.S. DEPARTMENT OF HEALTH, EDUCATION, AND WELFARE Public Health Service Center for Disease Control

National Institute for Occupational Safety and Health Division of Biomedical and Behavioral Science March 1977 
Mention of trade names or commercial products does not constitute endorsement or recommendation by the National Institute for Occupational Safety and Health,

DHEW (NIOSH) Publication No. 77-148 
The purpose of this investigation was to determine the types and distribution of shiftwork systems and the distribution of workers within the major shiftwork industries and service groups in the United States.

Sources of data utilized in fulfilling this task were agencies (e.g., U.S. Department of Labor, Bureau of Labor Statistics; U.S. Department of the Interior, etc.), management consulting firms for particular industries (e.g., Northern Textile Association), unions (e.g., United Mine Workers), and trade associations (e.g., Air Traffic Controllers Association). The most comprehensive data source was the Bureau of Labor Statistics, which maintains information regarding work starting times for major industries throughout the United States.

The results indicated that there are numerous shift schedules and many systems of rotation. These vary in complexity and differ across industries, companies, and occupations. The hospital, transportation, food processing, and health care industries/occupations were identified as employing the highest percentage and absolute number of shiftworkers, while the chemical, lumber and wood products, and textile industries were identified as among the lowest.

The authors discuss the lack of a central, systematic data source for obtaining information of shift scheduling and recommend directions for future research. 
CONTENTS

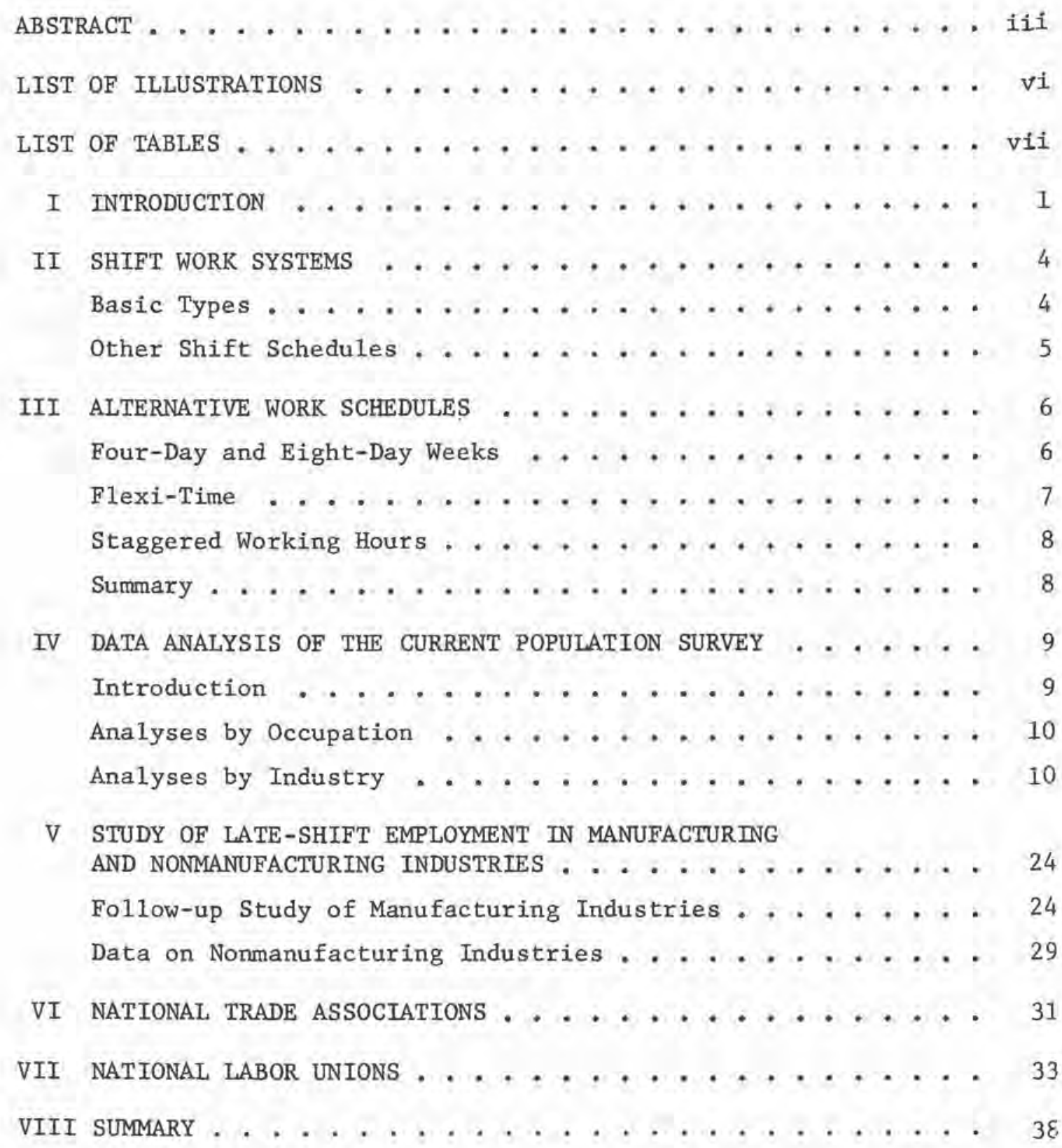




\section{APPENDICES}

A BUREAU OF LABOR STATISTICS CURRENT POPULATION

SURVEY (May 1975) RAW DATA ............ A-1

B LAWS GOVERNING SHIFT WORK ........... B-1

C PREMTUM PAY FOR SHIFT WORK ............. $\mathrm{c}-1$

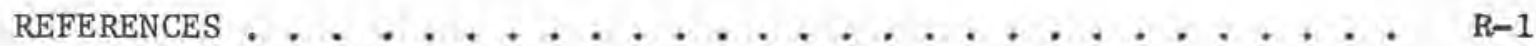




\section{ILLUSTRATIONS}

1 Major Occupational Groups. . . . . . . . . . . . . . . . 11

2 Occupational Groups Not on Shifts. . . . . . . . . . 12

3 Contrasting Service Industries ... . . . . . . . 21

4 Service and Goods Producing Industries I. . . . . . . 22

5 Service and Goods Producing Industries II. . . . . . . . . 23 
1 Blue Collar and Service Workers. . . . . . . . . 14

2 Major Sectors. . . . . . . . . . . . 14

3 Major Industry Groups. . . . . . . . . . . . . . 15

4 Selected Major Subgroupings of Industry. . . . . . . . 16

5 Manufacturing Industries . . . . . . . . . . . 17

6 Services.................. 18

7 Manufacturing and Service Industries . . . . . . . . . . 19

8 Industries Categorized by Numbers and Percentages of Shift Workers . . . . . . . . . . . . . . 20

9 The Incidence of Shift Operations in Selected Manufacturing Industries Illustrated by Two Dates. . . . . . 25

10 The Incidence of Shift Operations in Selected Nonmanufacturing Industries ............ 30

11 Beginning Times of Shifts by Labor Unions with 24-Hour Operations Indicated, Voluntary/Non-Voluntary Shift Work Practices Specified, and Number of Members Within Union. . 34

12 Shift Work . . . . . . . . . . . . . . . . . 35

13 Percentage of Workers Working Each Shift by Labor Union. . . 37

A-1 Beginning Times of Work for Wage/Salary Workers by Detailed Industry Group and FulI or Part-Time Status . . . A A-2

A-2 Beginning Times of Work for Wage/Salary Workers by Major Occupation Group and Full or Part-Time Status. . . . . . . A-4 


\section{INTRODUCTION}

Shift work has been a topic of concern as far back as the Thirteenth Gentury when European guilds protested against night work. As a result of the protests night work became virtually nonexistent until the advent of the Industrial Revolution when shift work began to reappear. It became prevalent after the establishment of the corporations in England, especially after 1791 . It did not take 1 ong for workers' reactions to night work to command attention from labor leaders and legislators. For example, by 1802, England had enacted a law restricting the working hours of apprentices. ${ }^{1 *}$ In the years that followed, additional labor-regulating laws were enacted as a result of negative reaction to shift work.

Around the turn of the century, England, Germany, France, and Switzerland created government agencies to control the working conditions of shift workers. Shift-work hours and wages in the United States are now regulated primarily by collective bargaining agreements with some stipulations in the Fair Labor Standards Act of 1974 (see Appendix B).

While this report does not attempt to measure the potential impact of shift-work related stress or worker adjustment and health, it is necessary to realize that the implications of shift work are significant to a large segment of the employed population. In 1972, the DirectorGeneral of the International Labour Organization expressed the need for study and reevaluation of shift schedules in his statement to the International Labour Conference:

Shift work, while no novelty, is increasing as a larger number of industries seek to take full advantage of greater mechanisation and automation by the use on a twenty-four hour basis of modern industrial equipment in a wider range of processes. Owing to the introduction of expensive data-processing equipment, it is also being extended to many nonmanual occupations where shift work was previously unknown. As the extent of shift work increases, the social problems which it presents grow and call for far more organised effort, by both management and society at large, to reduce its inconveniences and improve the social and other amenities available to the shift worker. Traditional shift-work rotation schedules could be re-examined and adapted to the needs not only of the undertaking but also of the individual worker and of society in general. ${ }^{2}$

\footnotetext{
*A11 numbered references are listed at the end of this report.
} 
Technical considerations dictate that shift work may be prevalent in a given industry whenever:

- The manufacture of goods produced by an industry is dependent on equipment or chemical reactions, which cannot be started and stopped within the duration of a single shift.

- A service rendered by a particular industry is in demand 24 hours a day.

Industries of the first type are called "continuous process" industries. Typical of such industries are steel mills which use furnaces taking several days to reach operating temperatures, oil refineries and chemical plants in which production may be continuous.

Industries in the second type are called "continuous operations," or "round-the-clock" industries. These include metropolitan police officers, firemen, nurses, and other health workers. Also included are the vast transportation, communications, and utilities industries as well as many smaller ones. As data in this report reflect, businesses serving the public--restaurants, hotels, theaters, amusement and recreation services, cleaning services, and the whole gamut of related industries--are experiencing an increased demand for services in the evenings or during the night.

Public transportation and public utilities have traditionally been shift work industries. Railroads, buses, airlines, and related transport services such as rental cars, railway express service, and freight forwarding are 24-hour operations in most major American cities. Utility services such as electric, gas, and sanitary as well as communications industries must provide for their customers' needs in accordance with their habits and the peak hour requirements for such services. The service occupations have high numbers of shift workers and even higher proportions of shift workers than the continuous process industries. The social needs for service personnel to work shifts are evident and not likely to diminish in the near future.

Shift work is also prevalent in industries with high ratios of capital equipment in relation to wages. The financial advantages of shift work became clear to Eighteenth Century employers when they recognized that the cost of capital is, in part, a function of time. Because shift work provides greater average output per unit time (i.e., over a 24-hour day), it spreads the time dependent costs of the capital over more units of output. This provides an advantage for the producer if other relative costs remain constant. Because other relative costs often do not remain constant (especially labor costs, because shift workers typically are paid more than nonshift workers), shift work is financially advantageous only if the savings in capital costs are greater than the losses in labor costs. Those industries, in which capital costs are high relative to labor costs, are called capital-intensive industries. The more capital intensive an industry is, the greater financial advantage it will likely realize by the use of shift work. Examples of industries with relatively 
high ratios of capital investment compared to wages are basic iron and steel, industrial chemicals, pulp, paper and paperboard, and synthetic fibers.

While the financial and technical advantages for industry and the social demands for service clearly keep shift work a reality in America (26.8\% of people go to work at times other than 7,8 , or 9 am), the impact of shift schedules on the worker is not clear. The fact that shift work exists does not tell us whether workers will successfully adapt to shift work. Assuming that some workers do adapt, we need to know more about how they accomplish this and what types of scheduling maximize their adaptation. These questions do not have clear answers at present, but need to be investigated.

The following sections of this report are an attempt to assess the nature and distribution of shift work throughout the country. What, if anything, could or should be done about shift work systems and/or workers' adaptation to shift work, is another issue entirely. 


\section{SHIFT WORK SYSTEMS}

Shift work is a system of fixed working hours with predetermined starting and finishing times, or a transition of one group of people who work in turn for another group. It enables management to better use the capital employed and to increase production capacity by a more efficient organization of human resources.

The most frequent starting and stopping times of shift industries are from 7 am to $3 \mathrm{pm}, 3 \mathrm{pm}$ to $11 \mathrm{pm}$, and $11 \mathrm{pm}$ to $7 \mathrm{am}$. The next most frequent hours are from $8 \mathrm{am}$ to $4 \mathrm{pm}, 4 \mathrm{pm}$ to midnight, and midnight to $8 \mathrm{am}$. The definitions of a late shift vary widely among companies. Work beginning on or after 10:30 am but before 7 pm may be considered a late shift. The third shift may begin when the second shift ends and extends into the morning hours.

\section{$\underline{\text { Basic Types }}$}

\section{Fixed, Rotating, and Oscillating Shifts}

Shift schedules vary from industry to industry, but are related to the nature of the industry. If the industry is a continuous processing one, or one in which capital investments are large in proportion to labor costs, the incidence of shift work will be apparent. The nature of the industry affects both the incidence and the type of work schedules used.

Fixed and Rotating--These two types were the shift work schedules most often described by trade associations, labor unions and industries. Fixed shifts are characterized by workers who regularly work either the day, evening or night schedules. Maintenance workers in some plants are on fixed shifts--generally the third shift if the other two are the production shifts.

O'Connor (1970) describes rotating shifts as characteristic of industrial chemicals and petroleum refining industries in which employees are required to work day, evening, or night schedules in rotation. He goes on to mention that some plants with rotating shifts operate 24 hours, seven days a week, with workers in processing jobs on the rotating shifts and maintenance workers assigned to fixed shifts. ${ }^{3}$

Oscillating Shifts--Another shift described by O'Connor (1970) is the oscillating shift whereby workers commonly alternate on a weekly basis between the day and evening shifts or between the evening and night shifts. BLS data indicate one of the few industries in which this is 
used is the synthetic fiber industry, but even there it represents only $1.3 \%$ (approximately 877 ) of the workers. ${ }^{4}$ The use of the oscillating shift as an alternative to rotating shifts is becoming more prevalent in the nursing profession.

\section{Other Shift Schedules}

\section{$\underline{\text { Split Shifts }}$}

A split shift can be defined as a working arrangement whereby the employee works a given number of hours, is released from work, and returns for additional work the same day. The split is the time between the two periods of work. Under some arrangements management may decide to have more than one split in a work day. servation:

In describing split shifts, Goldner (1952) makes the following ob-

Workers generally dislike split shifts because of the spread of time during which they are liable for duty and because of the inconvenience of traveling back and forth to work more than once a day. Many agreements prohibit split shifts or permit them only in emergencies. Without expressly referring to split shifts, some agreements in effect prohibit them implicitly by stipulating that the hours of work shall be continuous and consecutive. However, the daily operation of some industries--urban passenger transportation and restaurants, for example--is characterized by two or more peak periods with relatively little interim activity. Agreements in such industries usually permit the splitting of shifts, but regulate the number of splits permissible and the length of the spread of hours. For example, only one split in a shift may be permitted, the shift to be completed within 12 hours.

\section{$\underline{\text { Relief Shifts }}$}

The need for relief shift workers is created by the absence, illness or time off of regular workers. Since employees work a variety of shift schedules, as previously described, relief shifts reflect all possibilities of shift systems. For example, in a three-crew rotating shift system, the relief shift may be staffed according to seniority, thus enabling workers to have fixed shifts after a period of time in the establishment. However in other industries, workers bid for fixed shifts by seniority, and the only rotating shifts are those rellef shifts that cover the days off of other employees. 


\section{ALTERNATIVE WORK SCHEDULES}

The most common system of work scheduling involves a fixed starting time each day. Each employee must be at work at a regular hour and in many cases, must punch a time clock or sign an attendance record. Only in exceptional cases are individuals permitted to start and finish later than others. Day workers usually work two periods, one in the morning and the other after a break at noontime. An example of a typical day would be from $7: 30$ am to $4: 30 \mathrm{pm}$ or from 8 am to $5 \mathrm{pm}$. The break for lunch is generally from noon to $1 \mathrm{pm}$ with morning and afternoon coffee breaks.

There is no general agreement on the best length or workweek or scheduling of hours within that week. Innovations such as the four-day or eight-day weeks, flexi-time, and staggered working hours are being tried for a variety of reasons.

\section{Four-Day and Eight-Day Weeks}

The American Management Association in their publication, The FourDay Week, predicted that over the next decade a sizeable segment of American workers may be experiencing a workweek of four days. It was reported that in 1972, an estimated 100,000 employees (approximately one out of 840 American workers) in approximately 1,000 manufacturing companies, service and retail organizations, and municipal agencies were working four-day weeks. Whereas the four-day pioneers have been accurately described as small, predominantly nonunion, and nonurban manufacturing firms, or service and retail companies, the movement has spread increasingly to more urban-centered organizations. Four-day work weeks are being used in hospitals, insurance companies, and municipal agencies.

The American Management Association also examined the effects of the four-day week on shift arrangements and shift pattern changes. In their survey, they found that of the 127 four-day companies reporting shift schedules:

- 72 were single-shift operations

- 41 were two-shift operations

- 14 were three-shift operations.

Examples of seven-day continuous service operations cited were hospitals, law enforcement agencies, and small continuous-processing manufacturing firms. 
These examples discredit the misconception that four-day schedules cannot be applied to two- and three-shift continuous-process or continuous-service operations. The four-day week does not necessarily reflect the total number of days and hours that the business operates nor does it necessarily mean that a company operates four days a week and is closed for three days. Instead, the four-day week is a unique way of scheduling an individual employee's time or that of a group of employees.

The eight-day week consists of four 10-hour days followed by four days off. It is used primarily by firms which operate 10 hours a day for seven days a week. An example of a foundry operating on an eightday cycle, 20 hours a day, is described by Riva Poor (1970):

Two 10-hour shifts a day for two crews of two 10-hour shifts each. One crew ( 2 shifts) works 4 days while the other is off--alternating in 8-day cycles--4 days on, 4 days off. Operations go on routinely 20 hours a day, 7 days each calendar week--about 7,000 hours a year. ${ }^{7}$

Easing traffic congestion, increasing leisure time (more than half of the days in the year are free), facilitating recruitment, and improving productivity have all been attributed to both the four-day and the eight-day week.

\section{Flexi-Time}

Another rescheduling of work hours that has positive results for worker morale and productivity, as well as traffic congestion and other factors, has been the introduction of flexible hours.

Flexible-time was originated in Europe, and although it is still not widely used in the United States, it has been employed on an ad hoc basis for a long time by research, advertising and other companies where the employee is his/her own resource.

An employee is given considerable latitude in putting together time on a daily basis to meet the standard weekly requirement. The arrival and departure times may take place anywhere within three-hour periods at the beginning and end of the workday. This allows for different arrival, departure, and total time each day, and may include carryover of time debits or credits from week to week. ${ }^{8}$

In general, workers may start and leave work when they wish; however, they must be present during the core time which, for example, could extend from 9:00 am to 4:00 pm. Usually this condition contains a provision for a tolerance of some hours (e.g., plus or minus ten) which may be carried forward to the next month. 
Flexi-time helps to alleviate traffic jams both at the gates of the plant or at the time clock. People who need time off to take care of personal matters are encouraged to take time off during the flexible hours and make up the time later.

Another result of the more flexible hours has been the possibility for married women to reenter the labor market or to remain after they have children because their schedules can be made to suit their personal requirements as well as those of their employer.

\section{Staggered Working Hours}

One innovation in working hours has been the introduction of staggered working hours, particularly in large metropolitan areas. To alleviate the rush hour congestion, some firms and federal agencies have introduced starting and finishing times which are at staggered intervals. Employees are assigned or allowed to choose their starting times which in turn determine their finishing times.

\section{$\underline{\text { Sunmary }}$}

In summary, traditional and innovative work schedules and their impact on shift work have been described. It is apparent from the literature that not only the particular shift worked, but also the order of shift rotation are important factors in determining work performance level. Although many other considerations are significant (i.e., work pace, enviromental conditions, and physical demands) the described flexibility in work scheduling provides management with the opportunity to optimize productivity and job performance. 


\section{DATA ANALYSIS OF THE CURRENT POPULATION SURVEY}

\section{Introduction}

The Current Population Survey, May, 1975 (BLS data) from the Department of Labor is categorized by work starting times and finishing times. No definition of shift work is contained in the data and it is, therefore, necessary to define shift work in terms of starting times. As the BLS data show, the peak starting times for most Americans are 7:00, 8:00 and 9:00 am. For purposes of our analyses, we have defined shift work as work beginning at any time other than 7:00, 8:00, or 9:00 am. Strictly, speaking, it might be more appropriate to refer to these other times as atypical starting times rather than shifts; however, with the exception of retailers and farmers (discussed later in this report), our definition appears to delineate what are usually considered to be the conventional shifts.

Another limitation inherent in the BLS data is the inability to differentiate between those workers on fixed or rotating shifts. Because the data are listed by starting times, those rotating shift employees working the day shift (beginning times at 7:00, 8:00, or 9:00 am) at the time of the BLS survey are excluded.

Data on various types of workers in the United States are published by the BLS in the Current Population Survey. This survey is reported monthIy from a sample of about 47,000 households. Estimates in this report are for persons 16 years of age and over in the civilian noninstitutional population. In May of each year, the monthly survey data also include figures on the starting times of work. As noted, the data analyzed here are from May 1975.

Workers can be classified by their stated occupation or by the type of industry that employs them. The Current Population Survey reports starting times of workers by occupation and industry.

The first set of data in this section shows the beginning work times of wage and salary workers by major occupation group in which the workers had full- or part-time jobs. The second set of data show the beginning times of work of wage and salary workers by detailed industry group in which the workers had ful1- or part-time jobs.

In both sets the starting times of workers were grouped, giving 17 categories of starting times of: 12 to $1 \mathrm{am} ; 2$ to $3 \mathrm{am} ; 4$ to $5 \mathrm{am} ; 6 \mathrm{am}$; $7 \mathrm{am} ; 8 \mathrm{am} ; 9 \mathrm{am}$; 10 to $11 \mathrm{am} ; 12$ to $1 \mathrm{pm} ; 2$ to $3 \mathrm{pm} ; 4 \mathrm{pm} ; 5 \mathrm{pm} ; 6 \mathrm{pm}$; $7 \mathrm{pm} ; 8$ to $9 \mathrm{pm}$; 10 to $11 \mathrm{pm}$; and starting time not available. We excluded from our study those workers whose starting time at work was not available, giving 16 categories. 


\section{Analyses by Occupation}

Figure 1 shows the percentage of workers starting in each time segment for the major occupational groups: white collar; blue collar; service; and farm workers, and the overall percentages for starting times for a11 wage and salary workers in the United States.

Hedges (1975) found that in goods and service industries and in govermment, $40 \%$ of the workers start work at 8 am. Two other peaks occurred, one at $7 \mathrm{am}$, in manufacturing and mining industries, and one at $9 \mathrm{am}$, in finance. ${ }^{9}$

In Figure 2, we show the groups that begin work at the main peak, 8 am. Compared with the overall wage and salary graphs for the United States are white collar workers and three subgroupings of white collar occupations: clerical, managers, and professional technical.

These groups were then defined as nonshift groups and were excluded from further study, since they began work at a peak hour.

Two other groups were also excluded from further study: (1) farm workers, who tend to start work at 6 am (not a peak starting time for American workers), but who are definitely not on shifts; and (2) sales workers, who start at 10 am (also a non-peak hour), but who stop work near the peak stopping time of American workers.

What emerges, then, is a study of shift workers in the blue collar and service categories.

From the set of occupational data, a total number of shift workers was found for blue collar and service occupations. The percentage of shift workers in an occupation was defined as the total number of shift workers in an occupation divided by the total number of workers in an occupation in al1 starting hour categories, including $7 \mathrm{am}, 8 \mathrm{am}$, and 9 am.

Table 1 shows the total number of shift workers in blue collar and service occupations. Included in the table are the percentages of shift workers for the various occupational groups.

In this table there are two groups that perhaps are not true shift workers. "Laborers, except Farm Workers" includes such nonshift but pre-7 am starters as fishermen and garbage collectors. Private household workers may work shifts, but are probably independent agents and would be hard to study in depth as shift workers.

\section{Analyses by Industry}

The following tables are generated from the BLS data and are broken down by industry group. Here a total number of workers engaged in shift work was also calculated. The percentage of workers in shift work in 

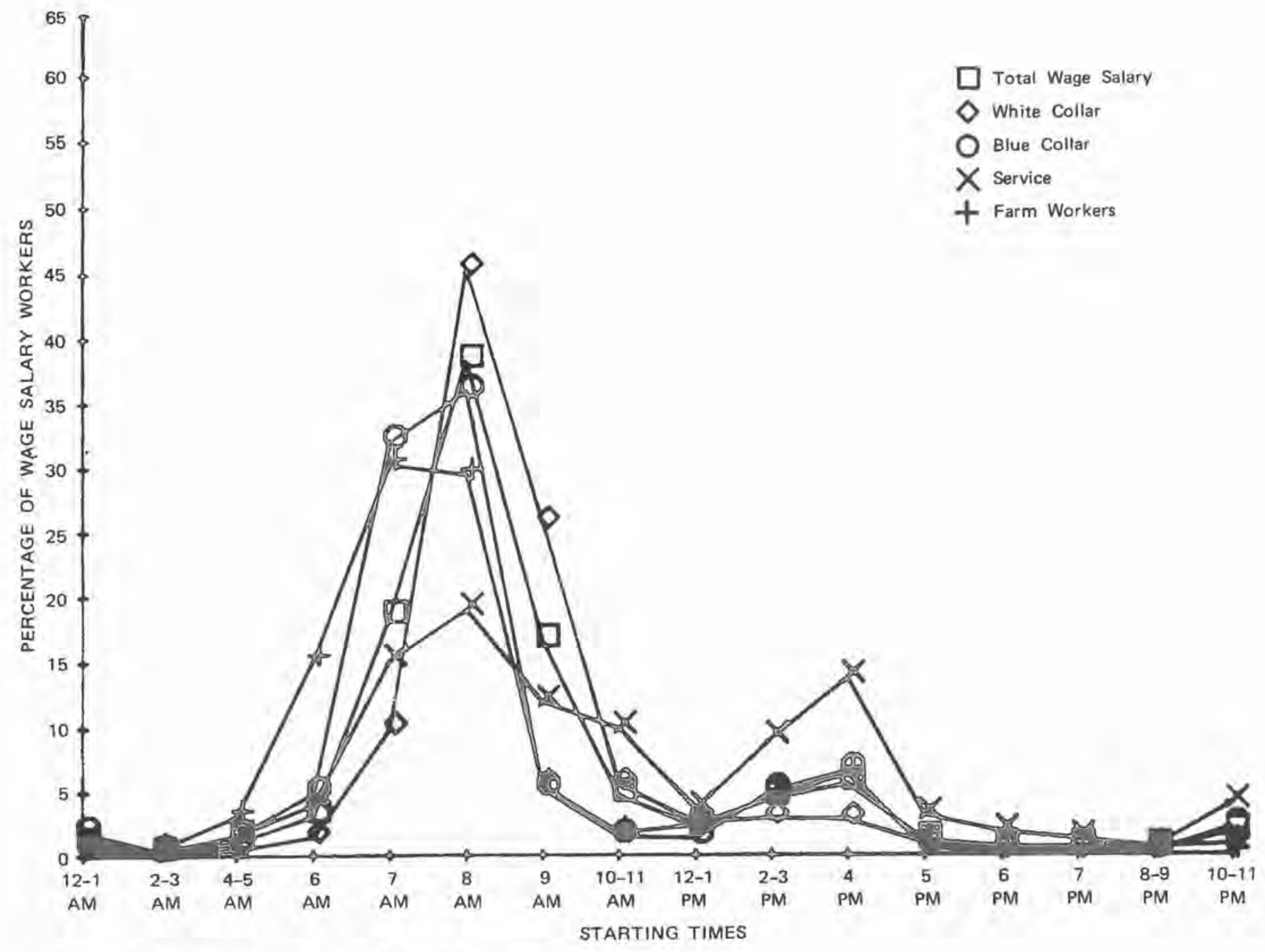

SOURCE: Current Population Survey. BLS, May 1975; SRI.

FIGURE 1 MAJOR OCCUPATIONAL GROUPS 


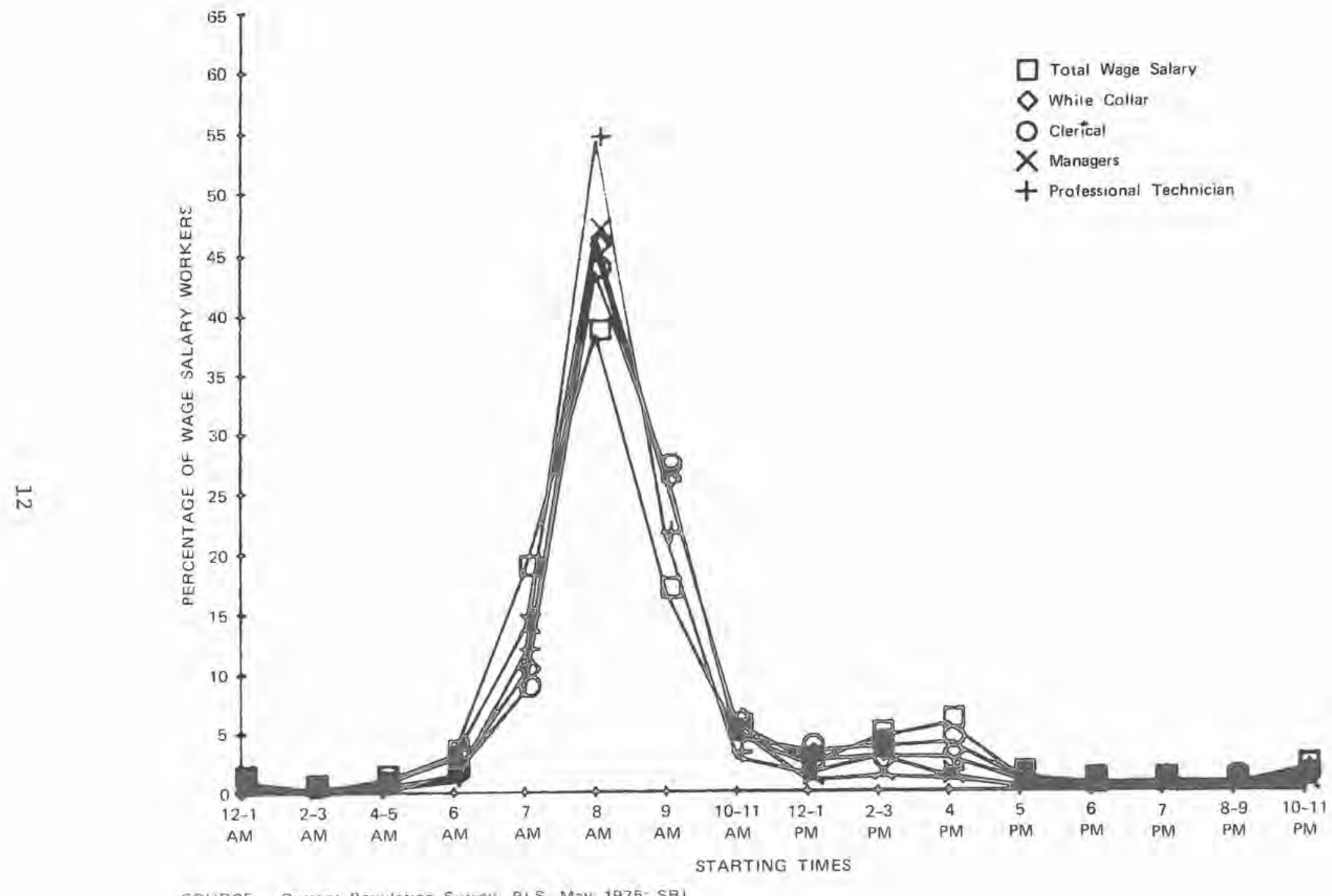

SOURCE Current Population Survey. BIS, May 1975: SRI

FIGURE 2 OCCUPATIONAL GROUPS NOT ON SHIFTS 
each grouping was defined as the total number of shift workers in each industry group divided by the total number of workers in all starting hour categories, including $7 \mathrm{am}, 8 \mathrm{am}$, and $9 \mathrm{am}$. Tables 2 through 8 show the total number and percentage of workers in an industry engaged in shift work from major sectors to specific industry groupings.

Table 3 shows the cormonly defined major industry groups. Trade, the industry group with the largest number of workers, is not considered in our analysis to be a true shift work industry because retail employees frequently begin work after 9 am. The next three industry groups containing large numbers of shift workers represent industries that will be further detailed in following tables under manufacturing, professional services, and transportation and public utilities.

In Table 4, the effect of retail sales workers' late starting gives this group a high shift work rating ( $47.6 \%$ ), although sales is not considered a shift work industry group.

Tables 5 and 6 show the number of shift workers and the percent of shift workers within the manufacturing and service industries. Table 7 combines the data of Tables 5 and 6 to show comparisons between the manufacturing and service industries.

Table 8 splits the industry groups of Table 7 into the following four categories:

- Large numbers of shift workers and large percentages of the total workers engaged in shift work.

- Sma11 numbers of shift workers and large percentages of the total workers engaged in shift work.

- Large numbers of shift workers and small percentages of the total workers engaged in shift work.

- Small numbers of shift workers and small percentages of the total workers engaged in shift work.

Table 8 contains all the data in Table 7 with the addition of a smaller category, manufacturing automobiles. A large number of shift workers in an industry group was defined as an $\mathrm{N}$ above the median of 221,000 (the median split for Table 7 data, plus industry data on manufacturing automobiles) and a large percentage of shift workers in an industry group was defined as a percentage greater than $26.8 \%$, the approximate percentage of all wage and salary workers in the United States who are shift workers.

This gives us a picture of those industry groups which are more homogeneous than others in terms of shift work. For example, cell A represents those industry groups with both a large percentage of shift workers as well as a large number of shift workers. 
Table 1

BLUE COLLAR AND SERVICE WORKERS

Shift

\begin{tabular}{|c|c|c|}
\hline Grouping & $\begin{array}{l}\text { Number } \\
(1,000 \mathrm{~s})\end{array}$ & $\begin{array}{l}\text { Workers } \\
\text { (percent) }\end{array}$ \\
\hline $\begin{array}{l}\text { Service workers, except } \\
\text { private household }\end{array}$ & 4,748 & $56.0 \%$ \\
\hline $\begin{array}{l}\text { Operatives, except trans- } \\
\text { port }\end{array}$ & 2,385 & 29.2 \\
\hline $\begin{array}{l}\text { Craftsmen and kindred } \\
\text { workers }\end{array}$ & 1,709 & 19.3 \\
\hline Laborers, except farm & 1,141 & 32.7 \\
\hline $\begin{array}{l}\text { Transport equipment } \\
\text { operatives }\end{array}$ & 940 & 37.2 \\
\hline Private household workers & 370 & 37.0 \\
\hline
\end{tabular}

Source: Current Population Survey, BLS, May 1975; SRI.

Table 2

MAJOR SECTORS

\begin{tabular}{lcc} 
Grouping & $\begin{array}{c}\text { Number } \\
(1,000 \mathrm{~s})\end{array}$ & $\begin{array}{c}\text { Shift } \\
\text { Workers } \\
\text { (percent) }\end{array}$ \\
\hline Service producing & 12,360 & $29.9 \%$ \\
Goods producing & 4,946 & 22.2 \\
Public administration & 846 & $20.2 \%$
\end{tabular}

Source: Current Population Survey, BLS, May 1975; SRI. 
Table 3

MAJOR INDUSTRY GROUPS

\begin{tabular}{|c|c|c|}
\hline Grouping & $\begin{array}{l}\text { Number } \\
(1,000 \mathrm{~s}) \\
\end{array}$ & $\begin{array}{c}\text { Shift } \\
\text { Workers } \\
\text { (percent) }\end{array}$ \\
\hline Trade & 5,665 & $40.8 \%$ \\
\hline Manufacturing & 4,068 & 24.3 \\
\hline Professional services & 3,271 & 23.4 \\
\hline $\begin{array}{l}\text { Transportation and public } \\
\text { utilities }\end{array}$ & 1,280 & 28.1 \\
\hline $\begin{array}{l}\text { Finance, insurance, and } \\
\text { real estate }\end{array}$ & 442 & 11.6 \\
\hline Business and repair services & 422 & 23.4 \\
\hline $\begin{array}{l}\text { Personal services excluding } \\
\text { private household }\end{array}$ & 392 & 27.4 \\
\hline Agriculture & 387 & 32.1 \\
\hline Entertainment and recreation & 376 & 63.4 \\
\hline Construction & 285 & 7.8 \\
\hline Mining & 204 & 30.4 \\
\hline
\end{tabular}

Source: Current Population Survey, BLS, May 1975; SRI 


\begin{tabular}{lccc}
\multicolumn{1}{c}{ Grouping } & $\begin{array}{c}\text { Number } \\
(1,000 \mathrm{~s})\end{array}$ & $\begin{array}{c}\text { Shift } \\
\text { Workers } \\
\text { (percent) }\end{array}$ \\
Retail & $\begin{array}{c}\text { Derable goods - manufacturing } \\
\text { Nondurable goods - manufacturing }\end{array}$ & 2,251 & $47.6 \%$ \\
Wholesale & 1,816 & 22.6 \\
Communications & 375 & 26.8 \\
Other public utilities & 180 & 13,5 \\
& 161 & 17.1 \\
& & 15.5
\end{tabular}

Sources: Current Population Survey, BLS, May 1975; SRI

In Table 8 , nine of the eleven shift work industry groups mentioned in the contract are represented. The two groups missing from the table are police and firemen and mass transit. Both of these groups are subcategories of larger industry groups and represent a finer breakdown of data than that given in the Current Population Survey.

Also, the contract category, "textiles," should not include both textiles and apparel. As seen in Tables 7 and 8 , textiles and appare 1 are two separate industries with different percentages of shift workers. The proposal category, energy production, is broader than the industry we have data on, i.e., petroleum and coal products.

Figures 3, 4, and 5 show graphs of the starting times of work for four representative industries, two service and two manufacturing. All four of these industries have a large percentage and a large number of shift workers in the industry. All four industries were also mentioned in the original contract.

Figure 3 graphs the two service industries, hospital and postal, against each other. Figures 4 and $5 \mathrm{graph}$ each of these service industries against a manufacturing industry; hospital against primary metal and postal against auto manufacture. Strikingly similar patterns of starting times can be seen between the blue collar and service industries. 


\begin{tabular}{|c|c|c|}
\hline Durable Goods & $\begin{array}{c}\begin{array}{c}\text { Number } \\
(1,000 \mathrm{~s}) \\
\end{array} \\
\end{array}$ & $\begin{array}{r}\text { Shift } \\
\text { Workers } \\
\text { (percent) } \\
\end{array}$ \\
\hline Transportation equipment & 498 & $29.9 \%$ \\
\hline Primary metal industries & 402 & 37.5 \\
\hline Machinery except electrical & 363 & 18.9 \\
\hline Electrical equipment and supplies & 278 & 14.8 \\
\hline Eabricated metal products & 261 & 23.6 \\
\hline Stone, clay, and glass products & 154 & 28.5 \\
\hline Lumber and wood products & 130 & 25.4 \\
\hline Instruments and related products & 56 & 12.9 \\
\hline Miscellaneous durable industries & 49 & 12.0 \\
\hline Furniture and fixtures & 33 & 7.7 \\
\hline $\begin{array}{l}\text { Ordnance } \\
\qquad \text { Nondurable Goods }\end{array}$ & 29 & 15.1 \\
\hline Food and kindred products & 593 & 42.7 \\
\hline Printing and publishing & 327 & 28.5 \\
\hline Textile mill products & 216 & 34.4 \\
\hline Chemical and allied products. & 199 & 19.7 \\
\hline Paper and allied products & 176 & 32.4 \\
\hline Rubber and plastic products & 174 & 35.0 \\
\hline Apparel and other textile products & 54 & 5.2 \\
\hline Petroleurn and coal products & 42 & 17.7 \\
\hline Tobaceo & 20 & 32.8 \\
\hline Leather and leather products & 17 & 7.3 \\
\hline
\end{tabular}

Sources: Current Population Survey, BLS, May 1975; SRI 
Table 6

SERVICES

\begin{tabular}{lcc}
\multicolumn{1}{c}{ Grouping } & $\begin{array}{c}\text { Number } \\
(1,000 \mathrm{~s})\end{array}$ & $\begin{array}{c}\text { Shift } \\
\text { Workers } \\
\text { (percent) }\end{array}$ \\
\hline Hospital & 1,117 & $36.9 \%$ \\
Education & 1,115 & 17.0 \\
Other transportation & 763 & 39.6 \\
Health & 572 & 29.9 \\
Private household & 507 & 40.7 \\
Postal & 277 & 45.8 \\
Other professional services & 246 & 17.3 \\
Welfare & 221 & 21.8 \\
Railroad and railway & & 32.6 \\
express service & 177 & \\
\end{tabular}

Sources: Current Population Survey, BLS, May 1975; SRI 
Table 7

MANUFACTURING AND SERVICE INDUSTRIES

(Sum of Tables 5 and 6 )

Grouping

Hospital

Education

Other transportation service

Food and kindred products

Health

Private household

Transportation equipment

Primary metal industries

Machinery except electrical

Printing and publishing

Electrical equipment and supplies

Postal

Fabricated metal products

Other professional services

Welfare

Textile mill products

Chemical and allied products

Railroad and railway express service

Paper and allied products

Rubber and plastic products

Stone, clay, and glass products

Lumber and wood products

Instruments and related products

Apparel and other textile products

Miscellaneous durable industries

Petroleum and coal products

Furniture and fixtures

Ordnance

Tobacco

Leather and leather products
Shift

Workers

$(1,000 \mathrm{~s}) \quad$ (percent)

1,117

$36.9 \%$

1,115

763

593

572

507

498

402

363

327

278

277

261

246

221

216

199

177

176

174

154

130

56

54

49

42

33

29

20

17
17. 0

39.6

42.7

29.9

40.7

29.9

37.5

18. 9

28.5

14.8

45.8

23.6

17.3

21.8

34.4

19.7

32.6

32.4

35.0

28.5

25.4

12.9

5.2

12.0

17.7

7.7

15. 1

32.8

7.3

Sources: Current Population Survey, BLS, May 1975; SRI 
Table 8

INDUSTRIES CATEGORIZED BY NUMBERS AND PERCENTAGES OF SHIFT WORKERS

\begin{tabular}{|c|c|c|}
\hline \multicolumn{3}{|c|}{ Industries Above $26.8 \%^{*}$ Shift Workers } \\
\hline Grouping & Numbers & Percent \\
\hline Hospital $\neq$ & $1,117,000$ & $36.94 \%$ \\
\hline Other transportation services & 763,000 & 39.64 \\
\hline Food and kindred products $s^{\neq}$ & 593,000 & 42.69 \\
\hline Heaith & 572,000 & 29.85 \\
\hline Private household & 507,000 & 40.66 \\
\hline Transportation equipment & 498,000 & 29.87 \\
\hline Primary metal industries ${ }^{\ddagger}$ & 402,000 & 37.47 \\
\hline Printing and publishing & 327,000 & 28.46 \\
\hline Manufacturing automobiles ${ }^{\ddagger}$ & 315,000 & 39.67 \\
\hline Postal ${ }^{t}$ & 277,000 & 45.79 \\
\hline
\end{tabular}

\begin{tabular}{|c|c|c|}
\hline Industries Below $26,8 \%$ * & Shift Workers & $\underline{B}^{\dagger}$ \\
\hline Grouping & Numbers & Percent \\
\hline Education & $1,115,000$ & $16.95 \%$ \\
\hline Machinery except electrical & 363,000 & 18.85 \\
\hline Electrical equipment and supplies ${ }^{\ddagger}$ & 278,000 & 14.79 \\
\hline Fabricated metal products & 261,000 & 23.58 \\
\hline other professional services & 246,000 & 17.30 \\
\hline
\end{tabular}

\begin{tabular}{|c|c|c|}
\hline Industries Above $26.8 \%$ & Shift Workers & $\underline{c}^{8}$ \\
\hline Grouping & Numbers & Percent \\
\hline 'Textile mill products ${ }^{\ddagger}$ & 216,000 & $34.39 \%$ \\
\hline $\begin{array}{l}\text { Railroad and railway express } \\
\text { service }\end{array}$ & 177,000 & 32.60 \\
\hline Paper and allied products & 176,000 & 32.35 \\
\hline $\begin{array}{l}\text { Rubber and plastic products } \\
\text { Stone, clay, and glass }\end{array}$ & 174,000 & 35.01 \\
\hline products & 154,000 & 28,47 \\
\hline Tobacco & 20,000 & 32.79 \\
\hline
\end{tabular}

\begin{tabular}{|c|c|c|}
\hline Industries Below $26.8 \%{ }^{*}$ & Shift Workers & \\
\hline Grouping & Numbers & Percent \\
\hline Welfare & 221,000 & $21.77 \%$ \\
\hline Chemical and allied products ${ }^{*}$ & 199,000 & 19.72 \\
\hline Lumber and wood products & 130,000 & 25.44 \\
\hline Instruments and related products & 56,000 & 12.93 \\
\hline $\begin{array}{l}\text { Apparel and other textile } \\
\text { products }{ }^{\ddagger}\end{array}$ & 54,000 & 5.23 \\
\hline Miscellaneous durable industries & 49,000 & 11.95 \\
\hline Petroleum and coal products ${ }^{\ddagger}$ & 42,000 & 17.72 \\
\hline Furniture and fixtures & 33,000 & 7.73 \\
\hline Ordnances & 29,000 & 15,10 \\
\hline Leather and 1eather products & 17,000 & 7.30 \\
\hline
\end{tabular}

* $26.8 \%$ is the percentage of shift workers in the country at large.

Industries above 221,000 shift workers, the median number of shift workers within U.S. industries.

Fhows industry cited in contract.

${ }^{\S}$ Industries 221,000 shift workers or below. 


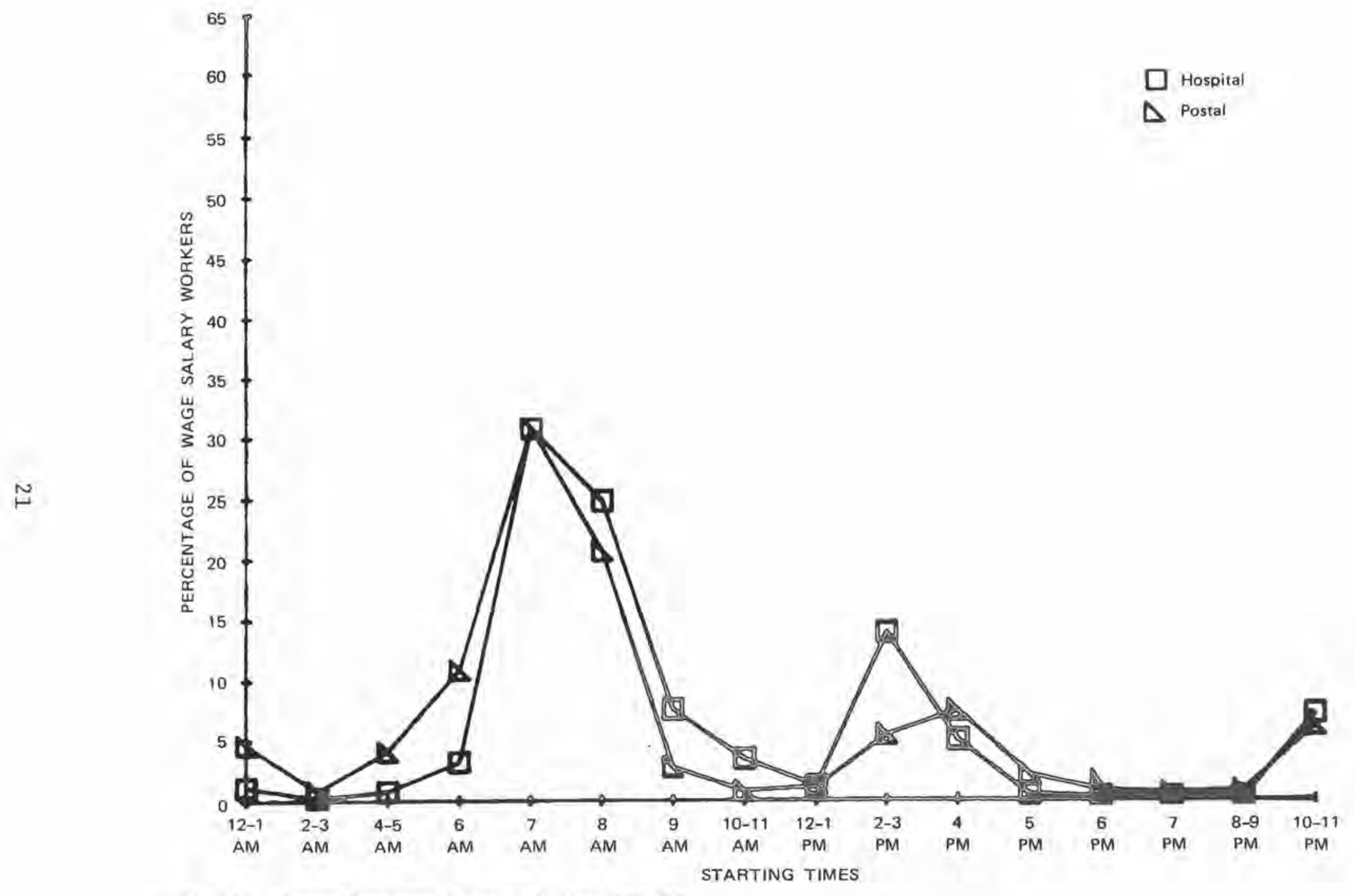

SOURCE: Current Population Survey, BLS, May 1975; SRI.

FIGURE 3 CONTRASTING SERVICE INDUSTRIES 


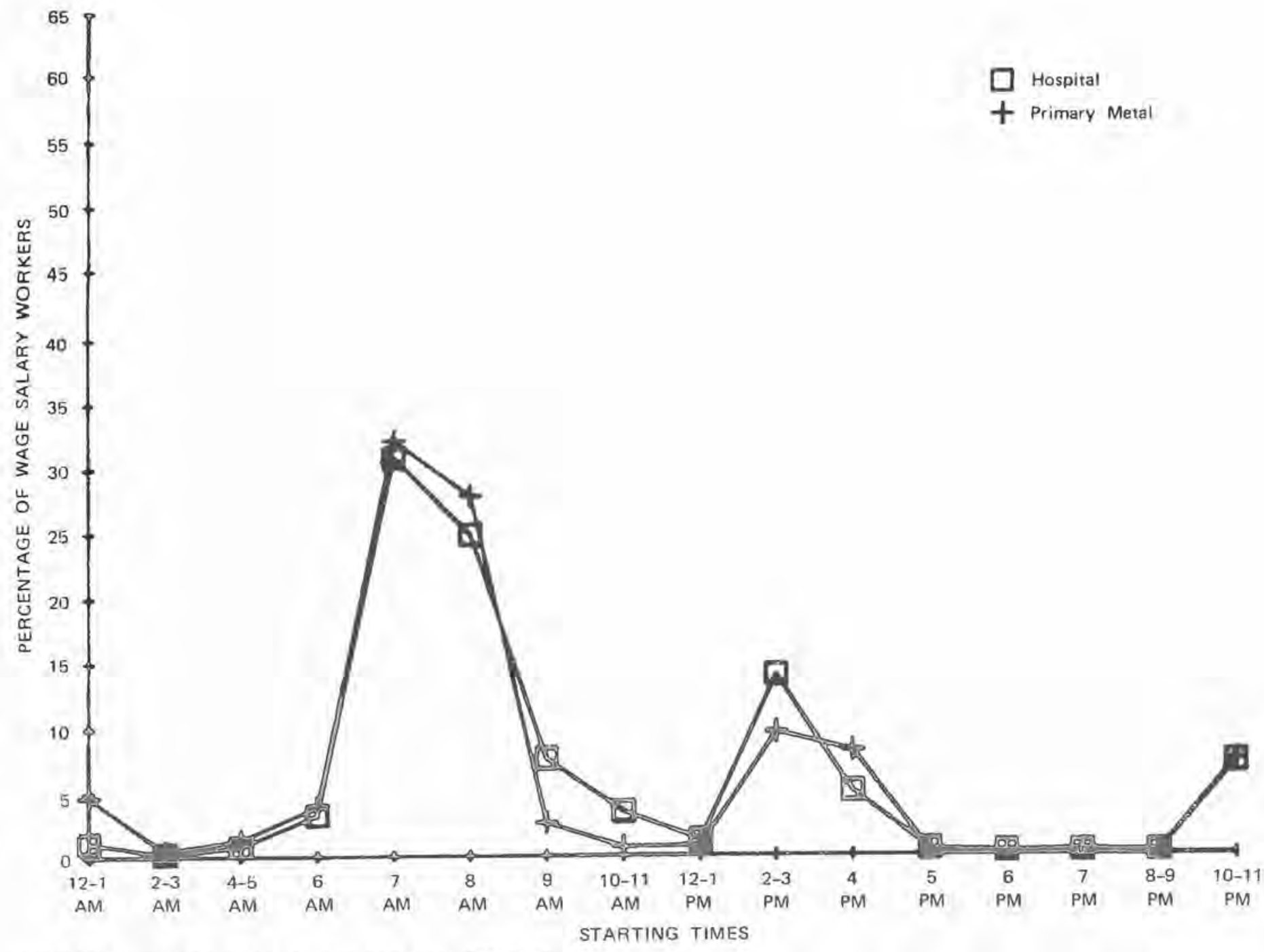

SOURCE: Current Population Survey, BLS, MaY 1975: SRI

FIGURE 4 SERVICE AND GOODS PRODUCING INDUSTRIES I 


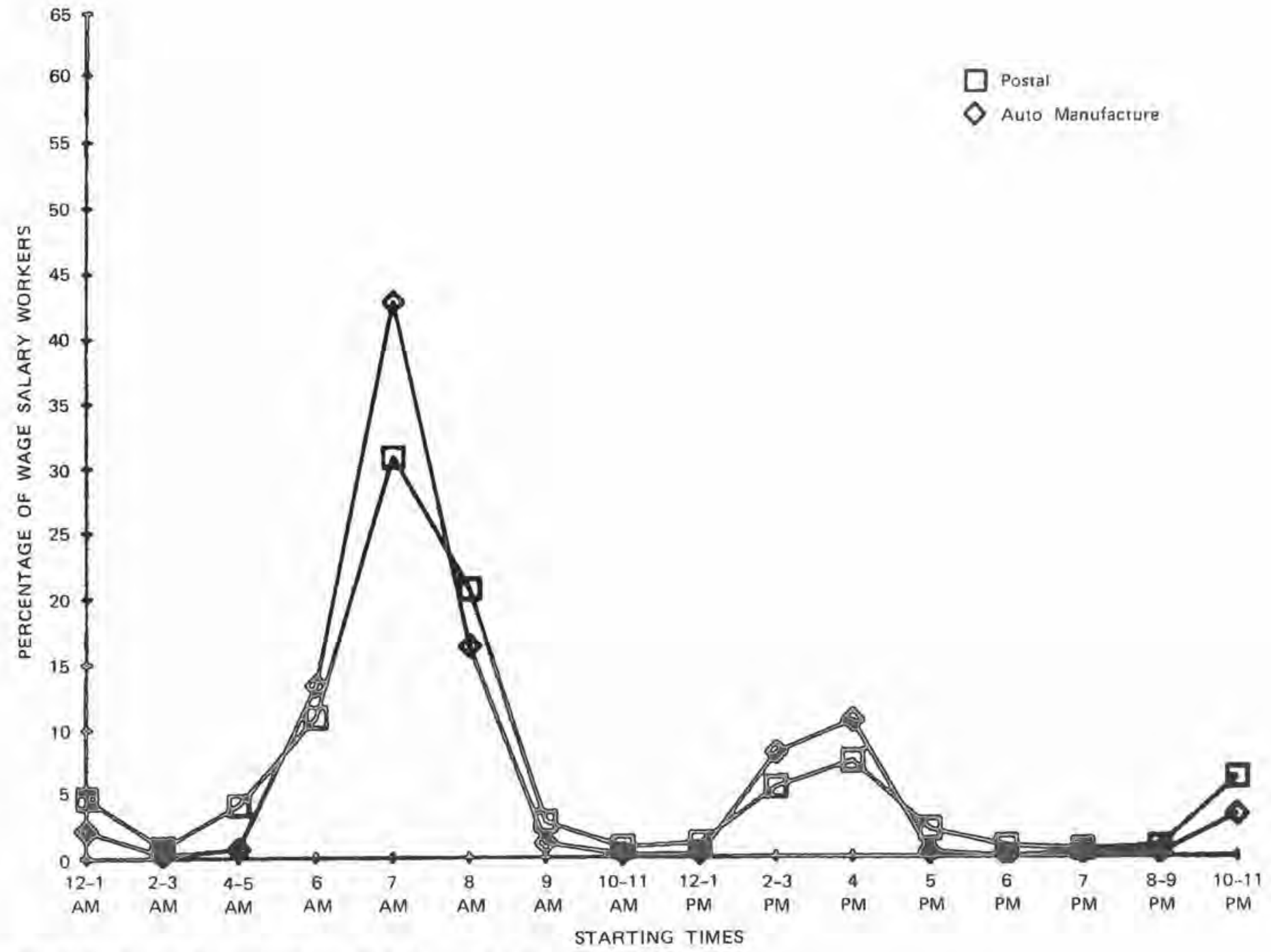

SOURCE: Current Population Survey, BLS, May 1975; SR1

FIGURE 5 SERVICE AND GOODS PRODUCING INDUSTRIES II 


\section{STUDY OF LATE-SHIFT EMPLOYMENT IN MANUFACTURING}

AND NONMANUFACTURING INDUSTRIES

\section{Follow-up Study of Manufacturing Industries*}

The proportions of 1ate-shift workers, those working shifts other than the day shift, varied greatly among individual industry groups. Shift work was not prevalent in such labor-intensive industries as apparel and other textile products. Among the industries studied, the highest proportions of late-shift workers--slightly more than $50 \%$--were in glass container manufacturing plants, cotton textile mills, and manmade fiber textiles. There has been little change in these proportions since $0^{\prime}$ Connor's findings in the 1960s. O'Connor (1970) found that the incidence of late shifts is generally highest in industries that are capital intensive, have continuous processing operations, and/or encounter increased demand for their product. The lowest proportions of late-shift workers--Iess than $2 \%$--were found in apparel industries, which are labor intensive and employ large numbers of women.

As stated previously, the nature of the industry (i.e., capitalintensive or labor-intensive) not only affects the incidence of late shifts but also influences the type of work schedule used. O'Connor (1970) describes three types of work schedules: fixed, oscillating, and rotating. Employees assigned to fixed shifts regularly work day, evening, or night schedules. On oscillating shifts, workers commonly alternate on a weekly basis, between the day and evening shift or between the evening and night shift. Rotating shifts in such industries as industrial chemicals and petroleum refining require employees to work day, evening, and night schedules successively. Some plants with rotating shifts operate 24 hours a day, seven days a week.

Of the 29 time comparisons shown in Table 9, the percentage of lateshift workers increased in 19 industries and declined in 10 over the eight year period, 1964-72. The largest increases in the proportions of late-shift workers (more than 20\%) were in cigarettes, sanitary food containers, and noncellulose synthetic fibers.

*

For the first survey dates shown, see industry wage surveys, U.S. Department of Labor, Bureau of Labor Statistics. For second survey dates shown, see Charles M. O'Connor, "Late Shift Employment in Manufacturing Industries," 1968 Month1y Labor Review (November 1970). For those industries showing one survey date only, no comparisons were possible. More recent statistics on these industries have not been collected by the Bureau of Labor statistics. 
THE INCIDENCE OF SHIFT OPERATIONS IN SELECTED MANUFACTURING INDUSTRIES ILLUSTRATED BY TWO DATES

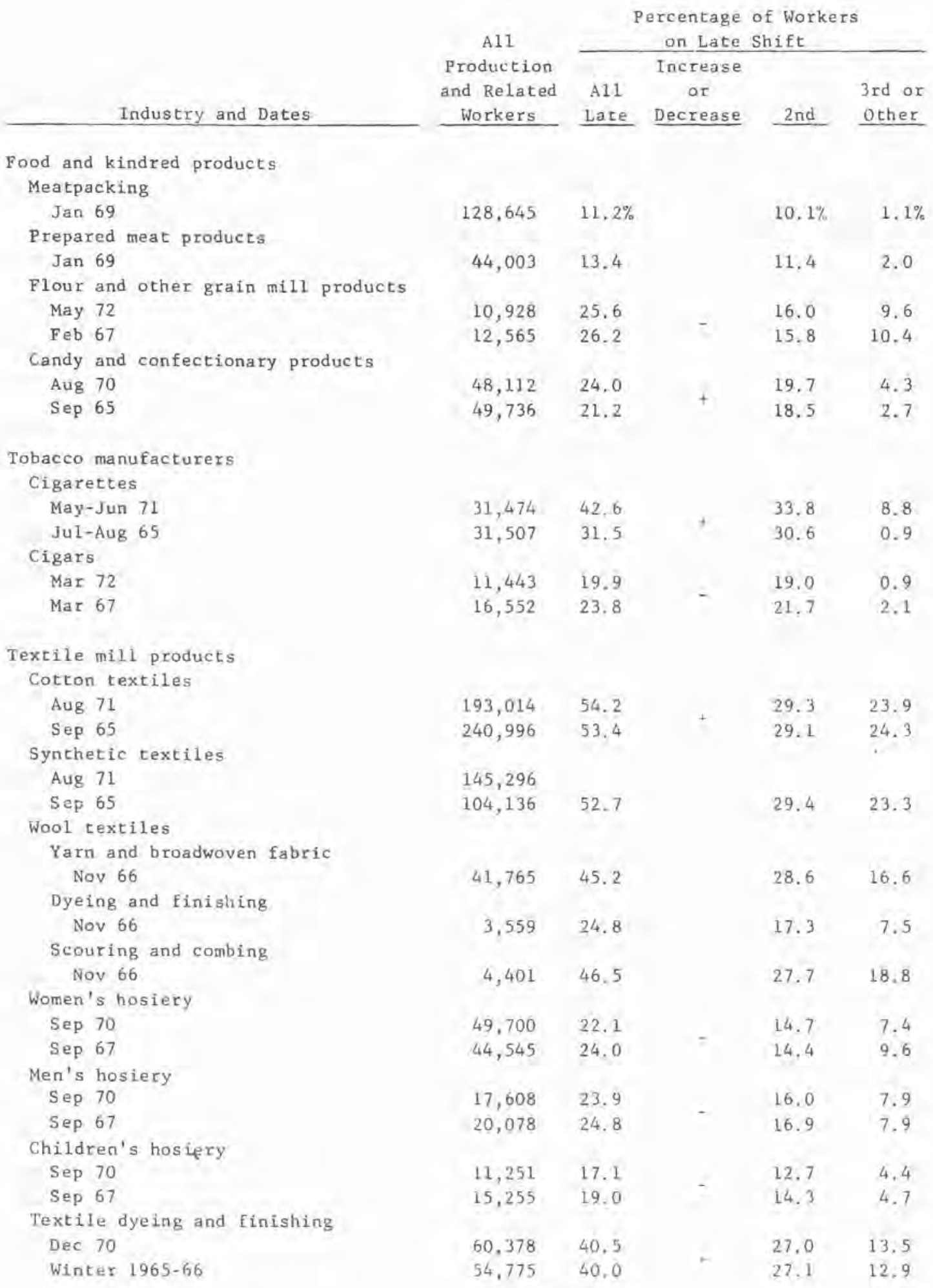




\begin{tabular}{|c|c|c|c|c|}
\hline \multirow{4}{*}{$\begin{array}{l}\text { Al1 } \\
\text { Production } \\
\text { and Related } \\
\text { Workers } \\
\end{array}$} & \multicolumn{4}{|c|}{$\begin{array}{c}\text { Percentage of Workers } \\
\text { on Late Shift }\end{array}$} \\
\hline & & Increase & & \\
\hline & A11 & or & & 3 rd or \\
\hline & Late & Decrease & 2 nd & other \\
\hline \multicolumn{5}{|l|}{103,000} \\
\hline 98,354 & $0.05 \%$ & & $0.05 \%$ & $0.05 \%$ \\
\hline \multicolumn{5}{|l|}{91,094} \\
\hline 92,537 & 1.1 & & 1.0 & 0.1 \\
\hline 62,775 & 0.8 & & 0.8 & $\cdots$ \\
\hline 130,803 & 4.6 & & 4.5 & 0.1 \\
\hline 197,919 & 46.5 & & 24.4 & 22.1 \\
\hline 32,040 & 29.4 & & 23.2 & 6.2 \\
\hline 29,201 & 26.9 & + & 21.7 & 5.2 \\
\hline 14,725 & 3,5 & & 3,4 & 0.1 \\
\hline 16,545 & 4.6 & - & 4.4 & 0.2 \\
\hline 70,601 & 38.1 & 4 & 31,4 & 6.7 \\
\hline 57,132 & 37.2 & + & 30.9 & 6.3 \\
\hline 19,437 & 48.7 & A & 29.2 & 19,5 \\
\hline 18,625 & 40.8 & 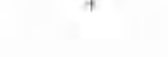 & 26.5 & 14.3 \\
\hline 12,530 & 26.1 & + & 20.1 & 6.0 \\
\hline 9,484 & 22.5 & + & 17.6 & 4.9 \\
\hline 171,762 & 36.0 & $t$ & 19.1 & 16. 9 \\
\hline 168,515 & 35.1 & + & 18.5 & 16.6 \\
\hline 19,551 & 42.6 & - & 21.0 & 21.6 \\
\hline 26,712 & 46.1 & - & 23.2 & 22.9 \\
\hline 47,877 & 54.1 & r & 27.3 & 26.8 \\
\hline 35,695 & 45.6 & $r$ & 23.0 & 22.6 \\
\hline 31,147 & 10.2 & & 7.8 & 2.4 \\
\hline 19,302 & 22,4 & & 14.5 & 7.9 \\
\hline 25,484 & 21.0 & - & 15.2 & 5.8 \\
\hline
\end{tabular}


Table 9 (Continued)

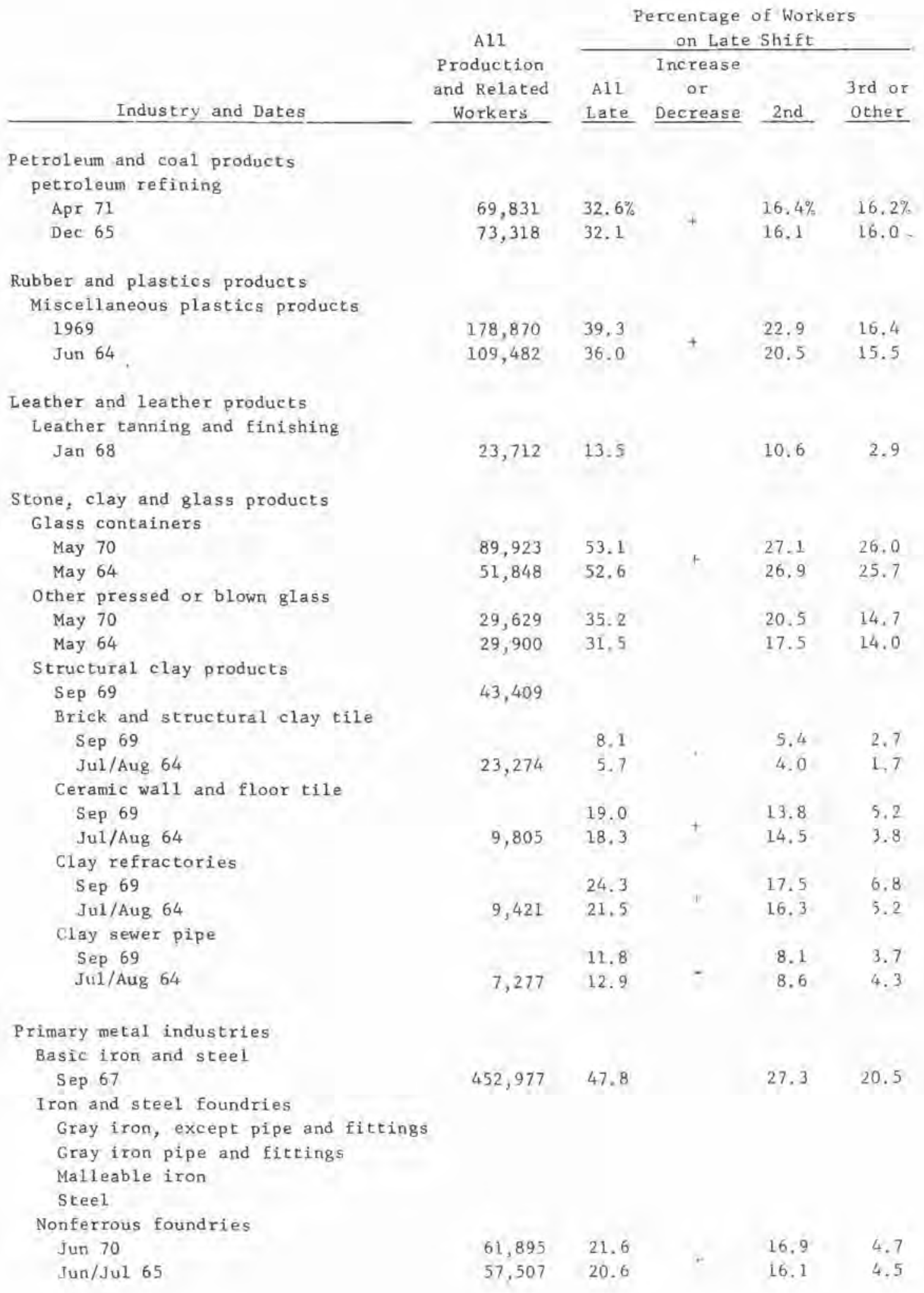


Table 9 (Concluded)

Industry and Dates

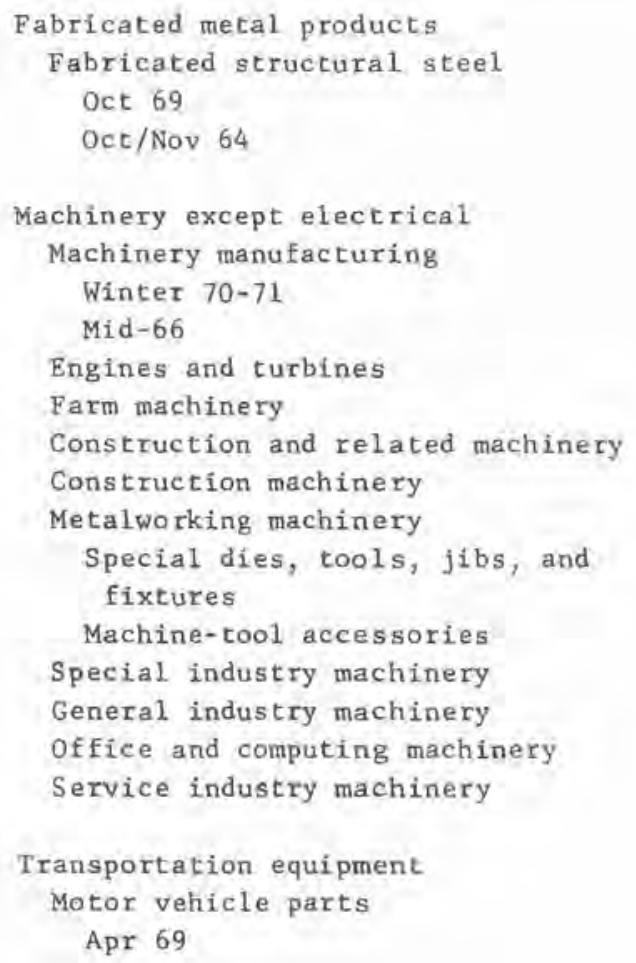

Percentage of Workers

A11 Production and Related Workers

on Late Shift

Increase

or

3 rd or

Late Dacrease 2nd other

64,557

$16.9 \%$

55,429

18.2

$1,205,800$

18.0

$1,171,278$

23.5

14.9

15. $3 \%$

16.5

\section{$1.6 \%$
1.7 \\ $1.6 \%$
1.7}

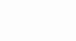

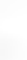


O'Connor (1970) reported declines in the proportions of late-shift workers in four industry groups in the 1960s--basic iron and stee1, cigarettes, flour and other grain mill products, and pressed or blown glass, except containers. Of these in the $1970 \mathrm{~s}$, the proportions have increased in cigarettes and pressed and blown glass, and have continued to decline in flour and other grain mill products. No figures for the 1970 s were available in the basic iron and steel industry.

\section{Data on Nonmanufacturing Industries}

An attempt was made to detenine the percentage of workers on late shifts in nonmanufacturing industries. Of the 17 nommanuacturing industries included in the industry wage surveys published by the Bureau of Labor Statistics, only four such wage surveys provided information on the percentage of workers working all late shifts, second shifts, and third or other shifts. While the industry wage surveys were available for most of the industries, these bulletins do not all provide data on shift practices as shown in Table 10. 
Table 10

THE INCIDENCE OF SHIFT OPERATIONS IN

SELECTED NONMANUFACTURING INDUSTRIES

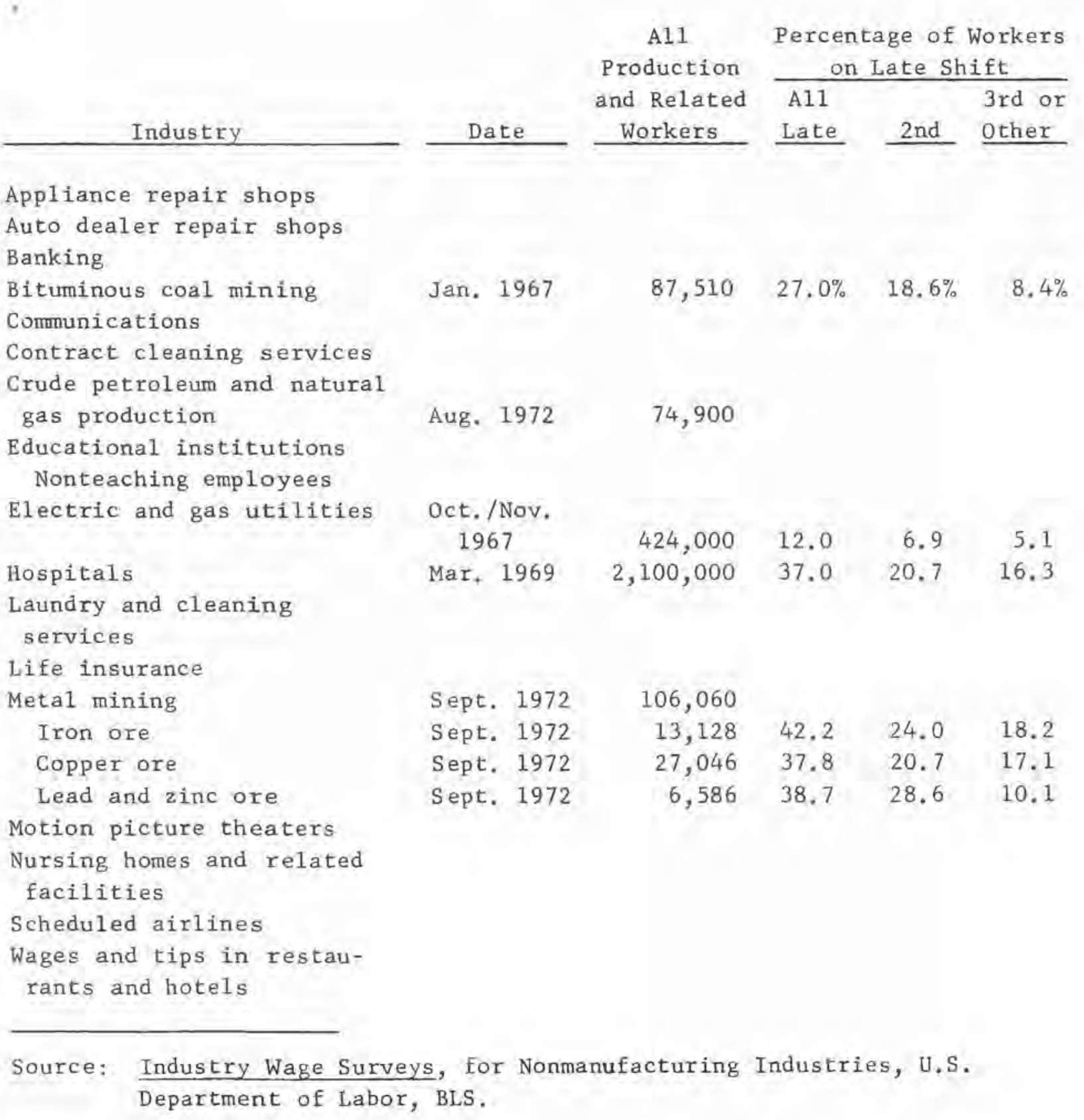




\section{NATIONAL TRADE ASSOCIATIONS}

In addition to surveying the existing literature, it seemed appropriate to contact the major trade associations in the country to see if they are keeping any records for the industry which they represented. They were requested to send existing records on man hours worked, starting times, descriptions of shifts, and distribution of workers by shift or to put us in touch with any organization which kept such records for their industry.

A 1 ist of approximately 150 associations was compiled from the Encyclopedia of Associations $^{10}$ using the following criteria:

(1) Size of membership. If it was a manufacturing association, then the majority of those selected held at least 24 company members. If it was an individual members' association (e.g., the Masters Brewers Association of America), then some groups have as many as 4,000 members.

(2) Directly related to the size of the association's membership was the consideration of the size of its staff. The presence of a research department, a library, or a newsletter was thought to be an indication of the capacity and the potential for having such information and statistics.

(3) Manufacturers were primarily selected because of the proclivity for shift work to be prevalent in this industry type.

(4) Those excluded associations which were primarily comprised of:

- Retailers or wholesalers.

- Suppliers to industry.

- Providers of marketing information to industry.

- Nutrition research, cleanliness promotion, etc.

- Some individual membership groups (i.e., World Dredging Association).

- Distributors, packers, brokers, suppliers, or warehousers.

- Major activities comprise public relations and merchandising.

(5) If one association appeared as if it might include many smaller associations, then we contacted the larger 
association. (For example, we contacted the National Soft

Drink Association and not the Root Beer Institute.)

It became apparent that the trade associations do not keep information on shift workers or shift work schedules. They either referred us to the BLS data or concluded that we would have to contact each industry individually for such information. In contrast to the responses from national union officials, those from the trade associations were not such that they could be quantified and tabulated in a meaningful form. 
Data were obtained primarily from union officials. Approximately 100 national labor unions were selected from the BLS booklet, Directory of National Unions and Employee Associations, 1974. Selection criteria were size of the union membership, number of local unions represented, and potential for having shift work systems. An attempt was made to elicit from these organizations any available information on:

- Existence of formal record keeping on the extent of shift work on various industries.

- Man hours worked.

- Starting times.

- Descriptions of shifts.

- Distribution of workers by shift.

To date, 20 national labor unions keeping such information have responded to our letters with enclosures and/or articles about work, workers' hours, and scheduling which provided the basis for further discussion on the extent of shift work in various industries. In addition, responses have been received from 10 other union officials who stated that no formal records are kept on the information we are seeking. The overall response rate to our initial contact was approximately $35 \%$. No follow-up on nonrespondents was made.

In general, we found that formal records are not being kept on the extent of shift work except perhaps by the individual employers themselves. Since shift work patterns seem to vary from company to company, from plant to plant, and even among different departments of the same plant, generalizations about these matters even within a particular industry group are difficult to make.

of the 20 national labor unions responding with information, 15 of these reported their members to be working 24-hour operations in the particular industry group (see Table 11). For those industry groups with rotating shifts, there is wide variation in the frequency with which workers generally rotate. Some reported that workers rotate every week, others every month, while still others rotate as many as three shifts per week (e.g., Professional Air Traffic Controllers Organization). In addition, the frequency with which workers rotate depends on the facility and varies from plant to plant and within different departments of the same plant. For the unions reporting the existence of shift work within their industries, $60 \%$ reported that shift work is not at all voluntary (see Table 12). 
Table 11

BEGINNING TDMES OF SHIFTS BY LABOR UNIONS WITH 24-HOUR OPERATIONS INDICATED,

VOLUNTARY/NON-VOLUNTARY SHIFT WORK PRACTICES SPECIFIED, AND NUMBER OF MEMBERS WITHIN UN1ON

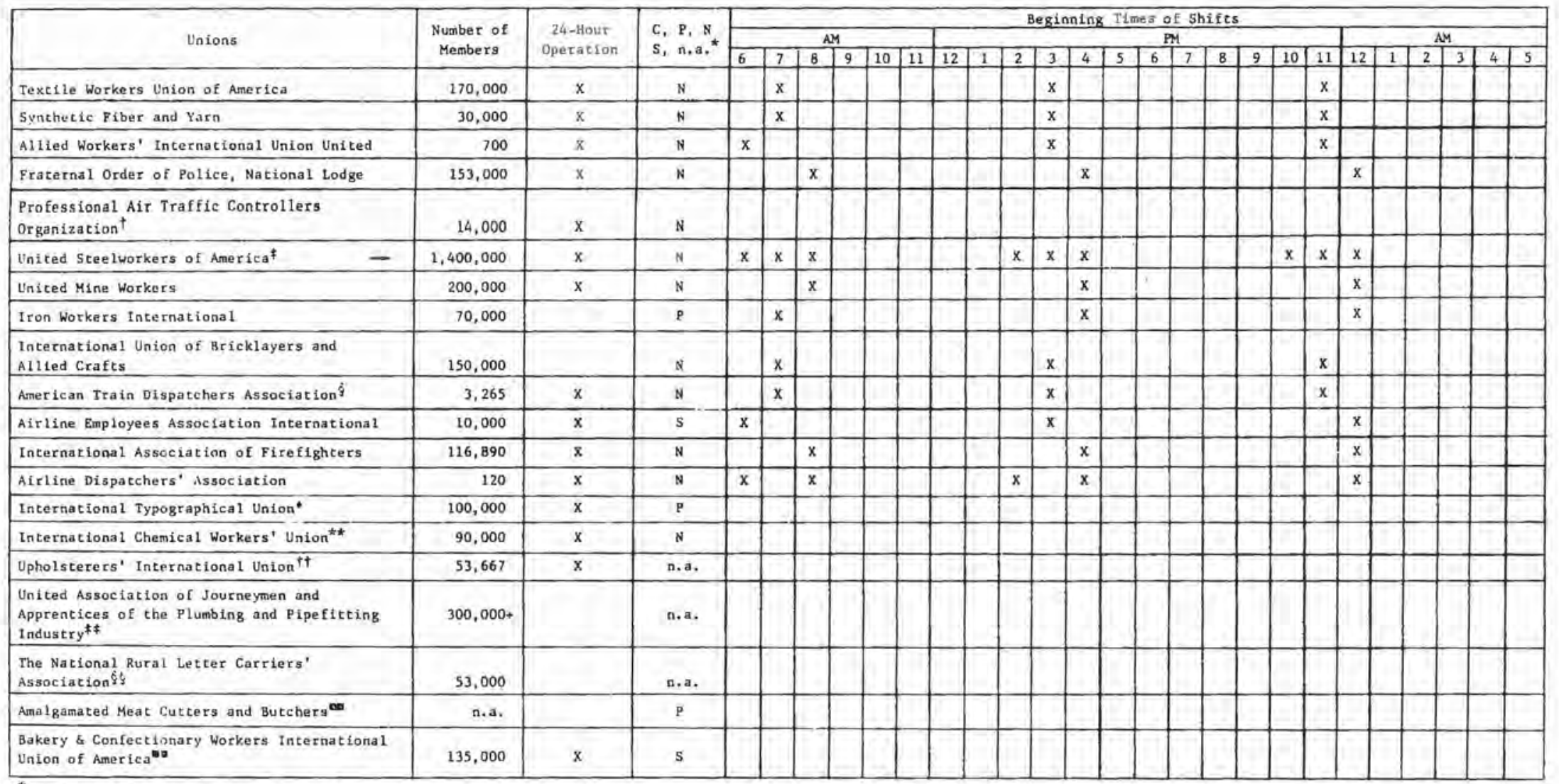

${ }^{*} \mathrm{C}=$ Completely voluntary; $\mathrm{P}=$ Partially voluntary; $\mathrm{N}=$ Not at all voluntary;

$\mathrm{S}=$ Eased on senioricy; n.a. = Information not avallable.

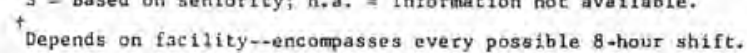

"Usually within these specified time periods:

a. Day shift includes all turns regularly scheduled to cormence between 6:00 am and $8 \mathrm{am}$, inclusive.

b. Afternoon shift includes all turns regularly scheduled to comnence between 2:00 pm and 4:00 pm, inclusive.

Might shift includes all turns regularly scheduled to comence between

10:00 pm and 12:00 midnight, inclusive.

ivaries throughout the country.

Sources: National Labor Unions; SRI

The printing and publishing industry does require much shift work to be performed, Hours workers report to work on different shifts are not available,

** No figures available, varies by plant.

${ }^{\dagger}$ No figures available, This union has only $5 \%$ shife work.

* Number of shift workers in this 'ndustry is negligible (0.1\%).

${ }^{8}$ No shift workers in this industry.

${ }^{\text {No }}$ figures available. 
Table 12

SHIFT WORK

\begin{tabular}{lccc}
\multicolumn{1}{c}{ Type } & Number & Percent \\
\cline { 1 - 2 } Completely voluntary & 0 & \\
Partially voluntary & 3 & $15.0 \%$ \\
Not at all voluntary & 12 & 60.0 \\
Based on seniority & 2 & 10.0 \\
No information available & 3 & 15.0 \\
Total & 20 & $100.0 \%$
\end{tabular}

Source: National Labor Unions; SRI 
A further breakdown by percentage of workers working each shift by union is shown in Table 13. Approximately $66 \%$ (12 of the 18 unions that provided percentage breakdowns by shifts) of the unions had $15 \%$ or more of their employees working shifts. 
PERCENTAGE OF WORKERS WORKING EACH SHIFT BY LABOR UNION

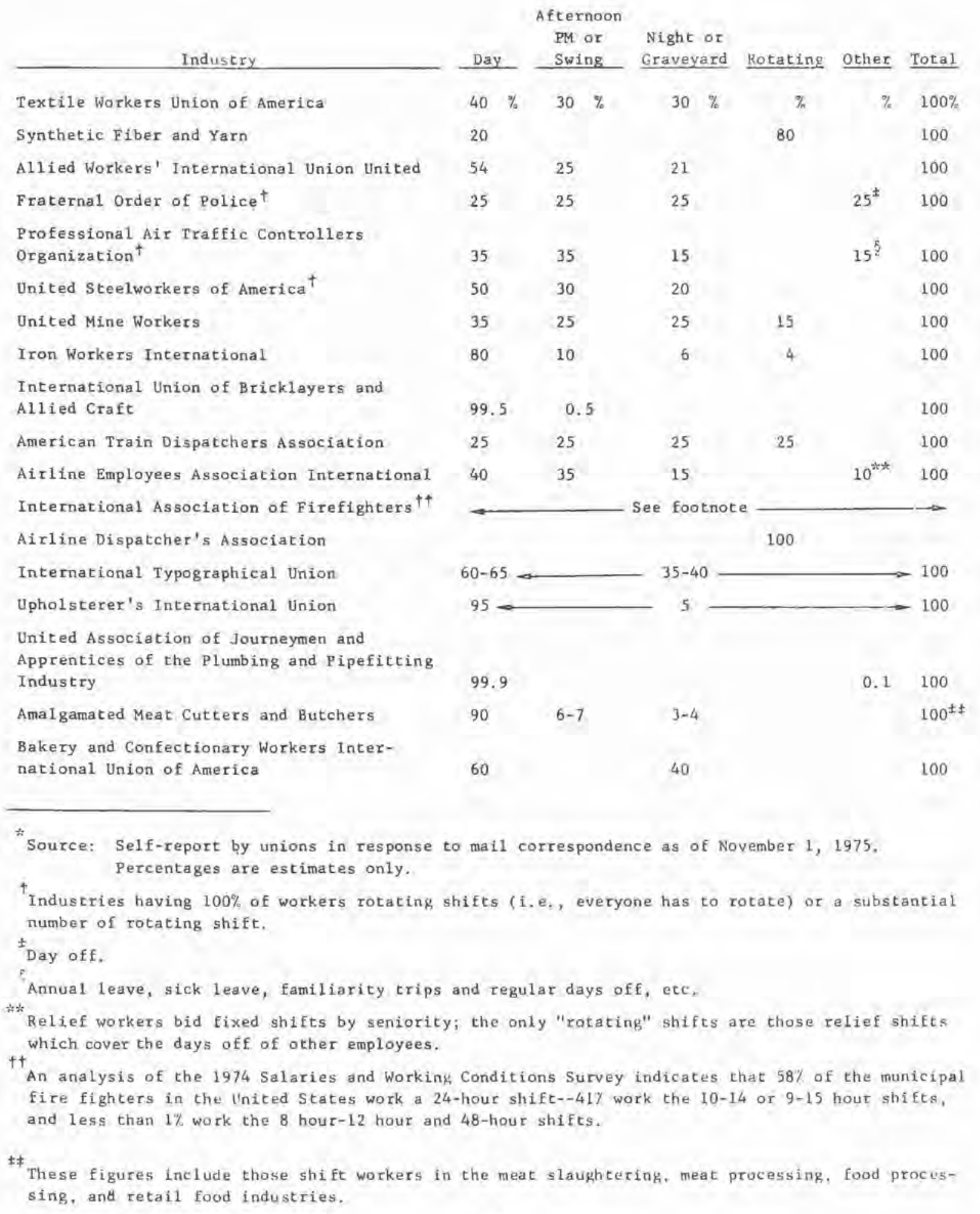


The practice of shiftwork has been receiving increasing attention over recent years from researchers in a variety of fields and professions. Such diverse disciplines as medicine, economics, physiology, psychology, human engineering, and sociology have expressed interest in the impact of shiftwork on their respective domains.

The purpose of this report was to attempt to identify the types and distribution of shiftwork systems and the number of workers employed in such systems for the major U.S. Industries and occupations. It was hoped that such information could be used by researchers to define areas of particular interest for intensive follow-up research.

At first, this task appeared to be straightforward. As we proceeded to search the literature and potential data sources, however, it soon became apparent that existing information on U.S. shiftwork practices is skeletal at best. The most comprehensive data was maintained by the Bureau of Labor Statistics (BLS) (Appendix A), which provided a comprehensive list of industry/occupational groups, as well as the distribution of workers by starting time within each of these groups. These data (presented in Table 8, p. 25 of the text) were used to identify those industries/occupations having the greatest incidence of shiftwork, categorized by absolute number and percentage of shiftworkers.

An attempt to be more comprehensive about the quantification of shiftwork systems proved fruitless. Contacts with national trade associations and labor unions revealed that no systematic records are maintained on shift scheduling or distribution within their respective organizations. Even the BLS data presented problems in that some industries/occupational categories were subsumed and included under others, making systematic comparisons difficult.

Regarding the precise nature of shiftwork systems, it would have been convenient to be able to report which type of shiftwork schedules were characteristic of which types of industries and services. As has already been mentioned, trade associations and national labor unions do not maintain these records, and the BLS data report only starting times, not rotation systems, within each industry. Even where some information on specific shift schedules was available for a particular industry/occupation, the data were extremely complex and cumbersome. For example, the International Association of Fire Fighters reports approximately 150 different types of work schedules for fire fighters alone. 
Probably even more striking than problems with the existing data was the skeletal picture of shift work that the quantitative data yielded. Therefore, to provide a context within which to interpret the data, this report attempted to present an enriched qualitative picture of shift work based on existing nonquantitative writings on the topic.

It has become clear that a consistent and coherent picture of the nature of shift work and the distribution of shift workers throughout the country is not contained in any existing document. It is hoped that this attempt to synthesize existing information and data will point more clearly to the need for a systematic approach to the study of shift work in the United States. 

Appendix A

BUREAU OF LABOR STATISTICS CURRENT POPULATION SURVEY

(May 1975) RAW DATA 
Table $h-1$

BEGINNING TIMES OF WURK FUR WAGR/SALARY WORKERS BY DETAILED INDUSTRY GROUP AND FULL. OK PART-TIME STATUS

lotal wage and salary workers

hood producing

Arriculetuce

Durabie nood

erdnunce

t.umber

Stone, clay alld glass pridicts

Primary metal indistries

Fahricated metal products

Hectrical equipment and supplies

transport extilipment

is

Aircrufe

dither transportation equipment

Aitstruments and rellated products

Misceltaneous qndustries

Foods and kind

Foods and kindred products

Tobacoo

lekcile mill product

Appatel and otlier textile products

Papert and allted produc ts

themicd and allied prodicts

petroleum wind cosal products

Rubber and plastics prodorts

Leather and produces

\begin{tabular}{|c|c|c|c|c|c|c|c|c|}
\hline \multirow[b]{2}{*}{ Tokal } & \multicolumn{7}{|c|}{$A M$} & \\
\hline & $12-1$ & $\underline{2-1}$ & $4-5$ & 6 & 7 & 8 & 9 & \\
\hline $72,552^{*}$ & 715 & 151 & 1563 & 2,126 & 12,506 & 25,924 & 11,195 & \\
\hline 23,618 & 353 & 63 & 244 & 1,019 & 7,160 & 8,766 & 1,400 & \\
\hline 1.295 & 3 & 5 & 35 & 155 & 346 & 374 & 94 & \\
\hline 709 & 36 & 4 & 10 & 38 & 180 & 263 & 25 & \\
\hline 3,880 & 5 & 0 & 13 & 105 & 1,114 & 2,080 & 167 & \\
\hline 17,734 & 309 & 54 & 186 & 720 & 3,519 & 6,043 & 1,114 & \\
\hline 10,551 & 160 & 14 & 54 & 413 & 3,729 & 3,470 & 511 & \\
\hline 210 & 0 & 0 & 0 & 3 & 54 & 106 & 3 & \\
\hline 544 & 6 & 5 & 9 & 34 & 219 & 154 & 8 & \\
\hline 452 & 0 & 2 & 0 & 11 & 236 & 120 & 35 & \\
\hline $5 b 3$ & 24 & 3 & 7 & 27 & 194 & 155 & 38 & \\
\hline 1,133 & 50 & 5 & 14 & 42 & 345 & 298 & 28 & \\
\hline 1,188 & $y$ & 0 & 8 & 63 & 427 & 366 & 53 & \\
\hline 2,009 & 15 & 2 & 9 & 55 & 734 & 718 & 111 & \\
\hline 1,783 & 21 & 1 & 3 & 13 & b10 & 644 & 98 & \\
\hline 1.771 & 28 & 2 & 8 & 126 & 693 & 443 & 33 & \\
\hline 844 & 17 & 2 & 5 & 106 & 340 & 130 & 4 & \\
\hline 500 & 6 & 0 & 2 & 8 & 146 & 200 & 15 & \\
\hline 426 & b & 0 & 2 & 12 & 207 & 113 & B & \\
\hline 450 & 1 & 0 & 2 & 4 & 113 & 212 & 52 & \\
\hline $44 \mathrm{I}$ & b & 0 & 0 & 13 & 105 & 203 & 53 & \\
\hline 7,183 & 158 & 35 & 127 & 307 & 1,790 & 2,574 & 603 & \\
\hline 1.446 & 21 & 27 & 105 & 165 & 370 & $36 \mathrm{~L}$ & 65 & \\
\hline 54 & 5 & 0 & 0 & 0 & 27 & 10 & 4 & \\
\hline 656 & 35 & 2 & 3 & 37 & 168 & 205 & 39 & \\
\hline 1,091 & 1 & 0 & 0 & b & 386 & $50 \mathrm{~B}$ & 87 & \\
\hline 572 & 10 & 0 & 1 & is & 174 & 172 & 22 & \\
\hline 1,218 & 15 & 4 & 10 & 34 & 161 & 452 & 209 & \\
\hline 1,064 & 31 & 0 & 6 & 29 & 178 & 502 & 130 & \\
\hline 242 & 10 & 1 & 0 & 3 & 46 & 133 & 16 & \\
\hline 530 & 18 & 1 & 1 & 20 & 130 & 169 & 24 & \\
\hline 249 & 2 & i) & 0 & ? & 148 & 62 & 6 & \\
\hline
\end{tabular}

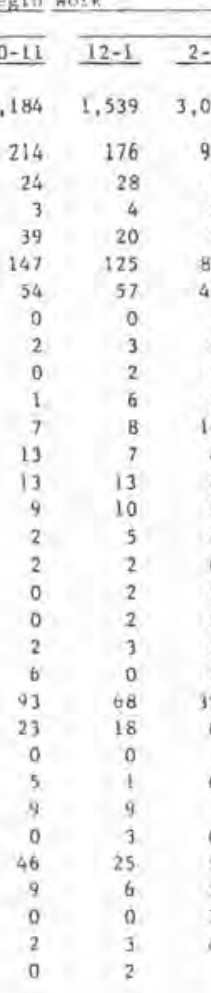

\begin{tabular}{|c|c|c|c|c|c|c|c|}
\hline & & $P M$ & & & & & \\
\hline $2-3$ & 4 & 5 & 6 & 7 & $\underline{8-9}$ & $10-11$ & N.A. \\
\hline 3,035 & 3,794 & 749 & 373 & 381 & 303 & 1,139 & $A, 77 \mathrm{~b}$ \\
\hline 941 & 1,171 & 75 & 59 & 93 & 52 & 486 & 1,347 \\
\hline 60 & 66 & 8 & 1 & 2 & 0 & 0 & 88 \\
\hline 35 & 33 & 3 & 3 & 5 & s & 25 & 39 \\
\hline 30 & 35 & 3 & 12 & 16 & 3 & 4 & 235 \\
\hline 815 & 1,037 & 61 & 43 & 70 & 44 & 457 & 990 \\
\hline 462 & 696 & 24 & 25 & 23 & 13 & 246 & 548 \\
\hline 4 & 17 & 0 & 2 & 0 & 0 & 3 & 17 \\
\hline 24 & 36 & 3 & 1 & 0 & 2 & 5 & 32 \\
\hline 11 & 5 & 0 & 0 & 0 & 0 & 2 & 29 \\
\hline 31 & 28 & 0 & 3 & 3 & 2 & 19 & 21 \\
\hline 102 & 87 & 3 & 2 & 3 & 2 & 77 & 60 \\
\hline 49 & 82 & 2 & i & ? & 0 & 20 & 80 \\
\hline 72 & 126 & 3 & 7 & I & 2 & 45 & 84 \\
\hline 55 & 91 & $?$ & 2 & 4 & 2 & 34 & 104 \\
\hline 88 & :90 & 6 & 4 & 3 & 2 & 34 & 194 \\
\hline 64 & 84 & 3 & 0 & 2 & 2 & 26 & 53 \\
\hline 13 & 54 & 3 & 4 & 2 & 0 & 5 & 36 \\
\hline it & 47 & 0 & 0 & 0 & 0 & i & 16 \\
\hline 17 & 20 & 0 & 3 & 0 & 3 & $i$ & 25 \\
\hline 10 & 8 & 0 & 0 & 1 & 0 & 5 & $3 t$ \\
\hline 353 & $3 / 61$ & 37 & 18 & 4? & 31 & 211 & 402 \\
\hline b) & 78 & 18 & 3 & 18 & 9 & 41 & 107 \\
\hline 8 & 3 & 0 & 0 & 1 & 0 & 3 & 1 \\
\hline 60 & 41 & 2 & 4 & 2 & a & 22 & 29 \\
\hline 6 & 10 & 0 & 3 & 4 & 2 & 4 & 53 \\
\hline 61 & 34 & 2 & 2 & D & 0 & 40 & 29 \\
\hline 54 & $\mathrm{H}_{3}$ & a & 6 & 10 & 8 & $2 b$ & 70 \\
\hline 37 & 46 & 1 & $a$ & 9 & 7 & 26 & 56 \\
\hline 10 & 5 & 3 & 0 & 2 & 0 & 8 & b \\
\hline 68 & 33 & 3 & 0 & 0 & 3 & 42 & 33 \\
\hline 3 & 3 & a & i) & 2 & 0 & 0 & 16 \\
\hline
\end{tabular}

These numbers represent thousands $(1000 \mathrm{~s})$.

Sourée: L.S. Department of Labor, Burcau of Labor Statistics 
Table A-1 (Concluded)

\begin{tabular}{|c|c|c|c|c|c|c|c|c|c|c|c|c|c|c|c|c|c|c|}
\hline & \multirow[b]{3}{*}{ Total } & \multicolumn{16}{|c|}{ Time Begin Work } & \multirow[b]{3}{*}{ N.A. } \\
\hline & & \multicolumn{8}{|c|}{ 1love begin } & \multicolumn{8}{|c|}{ PM } & \\
\hline & & $\underline{12-1}$ & $\underline{2-3}$ & $4-5$ & 6 & 7 & 8 & 9 & $\underline{10-11}$ & $\underline{12-1}$ & $2-3$ & 4 & 5 & 6 & 1 & $\underline{8-9}$ & $\underline{10-11}$ & \\
\hline Service producink & 44,468 & 28\% & $8 !$ & 371 & 978 & 4.686 & 15,100 & 9,177 & $2,9 i 6$ & 1,314 & 1,953 & 2,456 & 633 & 302 & 266 & 238 & 563 & 3,144 \\
\hline Transportation and poblis utsitties & 4,970 & 116 & 32 & 112 & 231 & 833 & 1,954 & 486 & 116 & 67 & 187 & 232 & 39 & 18 & 19 & 17 & 94 & 411 \\
\hline Raliroad and ralfway express & 580 & 25 & 5 & 8 & 15 & 129 & 211 & 24 & 5 & 3 & 42 & 52 & 2 & 2 & 3 & 0 & 15 & 37 \\
\hline Other transportativen & 2,158 & 66 & 25. & 86 & $17 !$ & 398 & 551 & 213 & 70 & 45 & 94 & 92 & 25 & 15 & 8 & 16 & 50 & 233 \\
\hline Comountcations & 1,134 & 12 & 2 & 0 & 17 & 97 & 580 & 193 & 33 & 14 & 22 & so & 9 & 0 & 5 & 2 & 14 & 84 \\
\hline Dether pubtic actitules & 1.098 & 13 & 0 & 18 & 28 & 209 & 615 & 56 & 8 & 4 & 29 & 38 & 3 & 2 & 3 & 0 & 15 & 37 \\
\hline Tráde & 14,852 & 54 & 31 & 163 & 337 & 1,267 & 4,032 & 2,918 & 1.637 & 631 & 645 & 1,455 & 399 & 72 & 76 & 75 & 90 & 971 \\
\hline Whulesale & 2,993 & 10 & ? & 34 & 88 & 421 & 1,388 & 588 & 58 & 45 & 41 & 45 & 8 & 4 & 10 & 13 & 12 & 219 \\
\hline Retail & 11,858 & 43 & 25 & 128 & 248 & 846 & 2,643 & 2,329 & 1,578 & -586 & 603 & 1,410 & 391 & 67 & 66 & 62 & 17 & 755 \\
\hline Finarice insurance and reat estate & 4,127 & 8 & 0 & 0 & 29 & 154 & 1,592 & 1,620 & 141 & 76 & 39 & 66 & 18 & 6 & 18 & 35 & 6 & 318 \\
\hline Private household & 1,428 & 7 & 0 & 6 & 22 & 109 & 313 & 318 & 114 & 55 & 60 & 79 & 21 & 83 & 45 & B & ? & 184 \\
\hline Miscellaneous service & 19,090 & 103 & 17 & yo & 360 & 2,324 & 7,206 & 3,835 & 908 & 486 & 1,023 & 624 & 156 & 123 & 107 & 104 & 366 & 1,258 \\
\hline Business and repale services & 1,976 & 27 & 0 & 12 & 26 & 149 & 805 & 426 & 62 & 45 & 44 & 121 & 27 & 13 & 12 & 18 & is & 175 \\
\hline Pergonal & 1,536 & 16 & 2 & 11 & 56 & 183 & 476 & 382 & 96 & 36 & 59 & 62 & 17 & 3 & 11 & a & 17 & 103 \\
\hline Entertainment and recreation & 642 & 0 & 1 & B & 13 & 62 & 89 & 66 & 75 & 29 & 38 & 64 & $4 B$ & 45 & 21 & 23 & 11 & 48 \\
\hline Professiona! & 14,882 & 60 & 15 & 36 & 262 & 1,924 & 5,806 & 2,955 & 675 & 374 & 882 & 378 & 64 & 52 & 64 & 56 & 323 & 927 \\
\hline Health & 2,035 & 16 & s & 12 & 53 & 307 & 557 & 480 & 70 & 63 & 175 & 64 & 9 & 10 & $s$ & 8 & 82 & 119 \\
\hline Hospital & 3,207 & 32 & 5 & 22 & 98 & 932 & 748 & 227 & 104 & 38 & 421 & 152 & 12 & 7 & 7 & 5 & 214 & 185 \\
\hline Welfare & 1,101 & 3 & 2 & 5 & 37 & 77 & 341 & 376 & 63 & 31 & 35 & 24 & 5 & 7 & 5 & 2 & 2 & 87 \\
\hline Educationn & 7,017 & 6 & 3 & 15 & 56 & 553 & 3,591 & 1,321 & 350 & 213 & 224 & 107 & 25 & 32 & 41 & 26 & 17 & 435 \\
\hline Other professional services & 1,522 & 2 & 0 & ] & 17 & 56 & 569 & 551 & 88 & 28. & 27 & 31 & 13 & 6 & 6 & 16 & y & 100 \\
\hline Forestry and fisherios & 54 & 0 & 0 & 3 & 3 & 7 & 29 & 5 & 0 & 2 & 0 & 0 & 0 & 0 & 0 & 0 & 0 & 6 \\
\hline Public administration & 4,466 & 74 & ? & 49 & 129 & 660 & 2,058 & 618 & 54 & 48 & 141 & 167 & 40 & 12 & 22 & 13 & 90 & 284 \\
\hline Postal & 635 & 28 & 5 & 25 & 66 & 186 & 125 & 17 & 5 & 7 & 33 & 45 & 13 & 5 & 3 & 5 & 37 & 29 \\
\hline Wher federal & 1,525 & 10 & 0 & , & 18 & 232 & 899 & 180 & 11 & 13 & 13 & 33 & 5 & 0 & 6 & 0 & 2 & 95 \\
\hline State & 712 & 4 & 2 & 10 & 7 & 53 & 371 & 140 & H & 16 & 23 & 13 & 4 & 0 & 2 & 3 & 14 & 44 \\
\hline Local & 1,595 & 31 & 0 & 6 & 38 & 189 & 663 & 280 & 30 & 13 & 72 & 75 & 19 & 7 & 11 & 5 & 38 & 116 \\
\hline
\end{tabular}


Table A-2

GEGINNING TIMES OF WORK DF WAGE/SALARY WORKERS BY MUNOR OCCUPATION GROUP AND EULL OR PART-TIME STATUS

Potal vage and salary workers thite collat workers

Professional rechnical and herced workers except fatm

Clerical and kundred workers

Blue collar workers

Ctaft and kindred workers

Operatives, except tranoport

Transport equipment operatives

Nonfarm laborets

Service vorkers

Private household workers

Other service workers

Farm workers

Farmers and tarn managera

Farm laboters and supervisors

\begin{tabular}{|c|c|c|c|c|c|c|c|c|c|c|c|c|c|c|c|c|c|}
\hline \multirow[b]{2}{*}{ Tocal } & \multicolumn{8}{|c|}{$A M$} & \multicolumn{8}{|c|}{$\mathrm{PM}$} & \multirow[b]{2}{*}{ N.A. } \\
\hline & $12-1$ & $2-3$ & $4-5$ & 6 & 7 & 8 & 9 & $10-11$ & $12-1$ & $2-3$ & 4 & 5 & 6 & 7 & $8-9$ & $10-11$ & \\
\hline 72,552 & 715 & 151 & 663 & 2,126 & 12,506 & 25,924 & 11,195 & 3,184 & 1,539 & 3,035 & 3.794 & 749 & 373 & 381 & 303 & 1,139 & $4,7,6$ \\
\hline 36,635 & 142 & 38 & 138 & 480 & 3,411 & 15,573 & 8.799 & 1,888 & 864 & 987 & 940 & 312 & 117 & 169 & 194 & 268 & 2,315 \\
\hline$\{1,41\}$ & 37 & 7 & 22 & 92 & 1,235 & 5,793 & $z, 260$ & 295 & 157 & 305 & 130 & 34 & 55 & 77 & 66 & 129 & 724 \\
\hline 1,032 & 27 & 12 & 44 & 186 & 894 & 3,053 & 1,715 & 336 & 61 & 78 & 67 & 22 & 4 & 16 & 28 & $2 t$ & 466 \\
\hline 4.459 & 4 & B & 19 & 36 & 194 & 1,124 & 1,370 & 66 & 211 & 137 & 223 & 10 & 24 & & & & 291 \\
\hline 13.727 & 73 & 12 & 52 & 166 & 1,088 & 5,604 & 3.455 & 58 & 435 & 467 & 520 & 148 & 34 & b1 & 80 & 112 & 834 \\
\hline 24,651 & 448 & B3 & 350 & 1,129 & 7,384 & 8,276 & 1,215 & 34 & 309 & 1,140 & 1,503 & 135 & 85 & 100 & 57 & 495 & 1,602 \\
\hline 9,410 & 151 & 22 & 66 & 322 & 2,637 & 4,016 & 496 & 10 & 55 & 299 & 428 & 33 & 23 & 37 & 12 & 16 & 552 \\
\hline 8,678 & 186 & 14 & 76 & 423 & 3.165 & 2,314 & 314 & B. & B & 511 & 658 & 36 & 30 & 32 & 16 & 229 & Sol \\
\hline 2,759 & 63 & 39 & 161 & & 718 & 726 & 143 & & & & 108 & 20 & 15 & & & & 234 \\
\hline 3,804 & 48 & 8 & 47 & & 865 & 1,220 & 262 & 9 & 109 & 214 & 309 & 46 & 17 & 19 & 16 & 78 & 315 \\
\hline 10,270 & 124 & 24 & 146 & 378 & 1,431 & 1,802 & 1,129 & 940 & 345 & 866 & 1,293 & 297 & 169 & 111 & 51 & 37 & 788 \\
\hline 1,151 & 4 & 0 & 4 & 22 & 90 & 275 & 266 & 8 & 36 & 35 & 35 & 19 & 76 & 43 & 8 & 1 & 148 \\
\hline 9,119 & 120 & 24 & 142 & 356 & 1,341 & 1,526 & 863 & 853 & 308 & 831 & 1,258 & 278 & 92 & 68 & 43 & 375 & 640 \\
\hline 997 & 2 & 5 & 29 & 140 & 280 & 273 & 52 & 17 & 22 & 42 & 59 & 5 & 1 & 0 & 0 & 0 & 71 \\
\hline 38 & 0 & 0 & 2 & 5 & 17 & 9 & 3 & 2 & 0 & 0 & 0 & 0 & 0 & 0 & 0 & 0 & 2 \\
\hline 959 & 2 & 5 & 28 & 135 & 263 & 264 & 49 & 15 & 22 & 42 & 59 & 5 & 1 & 0 & 0 & 0 & 70 \\
\hline
\end{tabular}

Source: U.S. Department of Labor, Bureau of Labor Statistics 
Appendix B

LAWS GOVERNING SHIFT WORK

B-1 


\section{Appendix B}

\section{IAWS GOVERNING SHIFT WORK}

Two federa1 acts, the Fair Labor Standards Act (FISA) and the WalshHealy Act, contain most of the laws regulating wages and hours in the United States. The first applies to employment in both government and private industry, while the second is additional regulations for employers who are government contractors.

Amendments to the Fair Labor Standards Act in 1974 extended coverage to federal and state governments, private household employees, and to retail and agricultural "conglomerates."

Until then, FLSA requirements had not applied to small stores of large retail chains, food service operations, bowling alleys, and seasonal and agricultural processing industries. These exemptions are being phased out by law. The amendments also raised the minimum wage to $\$ 2.30$ an hour, effective in several successive steps. ${ }^{11}$

The FISA does not stipulate that premiums or differentials be paid for shift work. However, almost every union agreement contains provisions for overtime and shift work even when shift work is virtually nonexistent or used infrequently by the industry. These agreements frequently delineate higher premiums for the shifts considered to be less desirable.

Shift work premiums established through collective bargaining agreements are designed to discourage the unnecessary scheduling of late shifts, and to provide extra compensation for work performed during undesirable hours. I

The FISA stipulates the following:

(1) Extra pay for shift work can either be paid at a higher straight-time rate or as overtime pay. If a higher straight-time rate, it must be included in the regularrate figures and cannot be credited towards FLSA overtime pay; if overtime pay, it may be ignored when calculating regular rates and applied against overtime pay required by the statute.

(2) When an employee is paid two shift rates during one week-for example, the day-shift rate and the night-shift rate-overtime pay under the FLSA is, as a general rule, based on the average rate. However, if agreed to by the employee before performance of overtime work, his FLSA 
overtime pay may be based on the shift rate in effect during the overtime hours.

(3) Whether or not a night premium is overtime pay or a shift differential must be decided before computing overtime pay under the FLSA. This is necessary because shift differentials are includable in the regular rate as higher straight-time earnings for undesirable hours, whereas overtime premiums are excludable as extra pay for hours worked in excess of basic daily standards. The statute allows night premiums falling in the overtime-pay category to be applied against the FLSA indebtedness, but shift differentials do not qualify as credits.

An employee who ordinarily works the night shift will most likely be paid the night premium as a part of his regular wages. On the other hand, an employee assigned to the day shift, who works exceptionally long hours which carry over into night work, might be paid premium rates as overtime because of excess hours. Second, third, graveyard, and swing shift differentials (whether a percent of base rates, additional cents per hour or eight hours pay for seven hours work) constitute higher straight-time pay for undesirable hours. But an employee working one of these shifts might also be paid true statutory overtime if he is paid a higher rate for working longer hours than those called for on his shift.

A particular employee's straight-time and overtime hours are determined by his own work schedule, and not necessarily by the straight-time and overtime hours of the particular shift on which he happens to be working.

(4) Extra compensation paid to employees for work performed before and after their regular working hours are known as pre-shift and post-shift premiums. There are two possible ways of qualifying such premiums as true overtime pay under the FLSA:

- Premiums paid for hours worked in excess of daily standards, in which case the premium rate may be less than 150 percent of straight-time rates.

- Premiums paid for hours worked outside of clock-time days, in which case the premium rate must be $150 \%$ of straight-time rates, the basic workday must not exceed eight hours, and these standards must be set up by a union contract or an employment agreement.

Pre-shift and post-shift premiums which qualify as overtime pay under the FLSA may be ignored when computing regular rates and may be applied towards any overtime pay owing under the statute. However, if these premiums do not qualify as statutory overtime pay, they become a part of the employee's straight-time insofar as the FLSA is concerned and must be included in computation of his overtime pay. 13 

Appendix C

PREMIUM PAY FOR SHIFT WORK

$$
\text { C-1 }
$$


Appendix C

PREMIUM PAY FOR SHIFT WORK

During the past thirty-five years, there has been a marked increase in various forms of premium pay for overtime, shift work, work on Saturday or Sunday or on holldays as well as increased benefits in the form of programs--medical insurance, old-age and unemployment insurance and so on. Supplementary compensation appears to have increased relatively more rapidly than direct wages, so that it represents a large proportion of total compensation. The impact of collective bargaining agreements on shift work over the years has been to make it more profitable for workers and more costly for employers; however, differential pay for shift work in particular has not kept pace with day-shift wage levels.

In Hours of Work, it is noted that collective bargaining agreements generally do not prohibit night work entirely, but often require the payment of a wage differential as compensation for the undesirable features. Shift premiums established through collective bargaining are often designed to serve a dual purpose: (1) to deter or penalize the unnecessary scheduling of late shifts, and (2) to provide extra compensation for work performed during undesirable hours. ${ }^{14}$

Restrictions on night shifts are affected in some agreements by a provision that work performed before or after the regular hours must be paid for at the overtime rate, generally time and a half.

According to BLS, nearly all manufacturing industries pay shift differentials ( $95 \%$ in 1967-1968).15 They average about 10 cents an hour for the second shift and 15 cents an hour for the third shift. ${ }^{16}$

BLS has analyzed 620 collective bargaining agreements in effect in 1971. These agreements cover 4.9 million workers in total and each agreement covers 2,000 workers or more. Shift differential provisions by industry are indicated below: 
Shift differentials in agreements covering 2,000 workers or more by industry, 1971

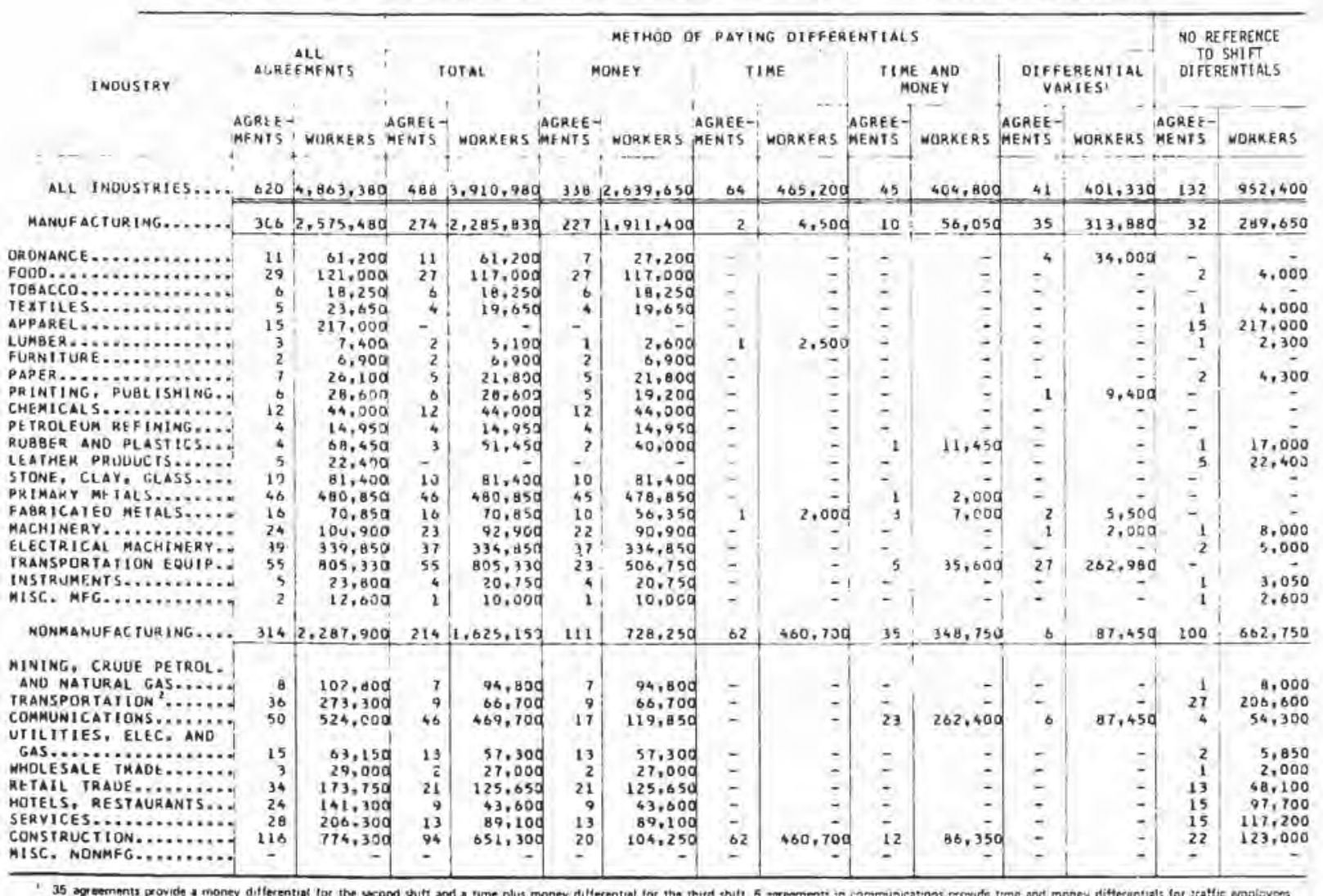

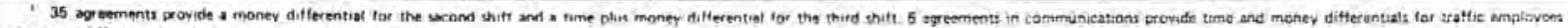
and inonav dilterentalis onty for plant and other moloyser

Source: "Characteristics of Agreements Covering 2,000 Workers or More," Bulletin 1729, BLS, U.S. Department of Labor (1972). 

REFERENCES

R-1 


\section{REFERENCES}

1. Mott, P. E., Mann, F. C., Mcloughlin, Q., and Warwick, D. P. Shift Work. Ann Arbor, Michigan, University of Michigan Press, 1965.

2. "Technology for Freedom: The International Labour Organization Contribution." Report of Director-General, 58th Session, Geneva, 1972. Part I, p. 40, International Labour Conference.

3. O'Connor, C. M. "Late Shift Employment in Manufacturing Industries." Month1y Labor Review, November 1970, BLS, U.S. Department of Labor.

4. "Industry Wage Survey, Synthetic Fibers, December 1970." Bulletin 1740, BLS, U.S. Department of Labor, 1972.

5. Goldner, W. Hours of Work. Berkeley, California. Institute of Industrial Relations, 1952, pp. 55-56.

6. Wheeler, K., Gurman, R., and Tarnowieski, 0. The Four-Day Week. American Management Association, Inc., 1972, pp. 6-10.

7. Poor, R. (Ed.) 4 Days, 40 Hours: Reporting a Revolution in Work and Leisure. Cambridge, Massachusetts. Bursk and Poor Publishing, 1970, pp. 169-170.

8. Glickman, A. A., and Brown, Z. H. Changing Schedules of Work Patterns and Implications. The W. E. Upjohn Institute for Employment Research, June 1974, p. 6.

9. Hedges, J. N. "Work Schedules and the Rush Hour." Monthly Labor Review. BLS, U.S. Department of Labor, July 1975, pp. 43-47.

10. Fish, M. (Ed.) Encyclopedia of Associations. Detroit, Michigan. National Organization of the United States, Gale Research Co., 1975, Vol. 1, pp. 15-243.

11. 1974 Guidebook to Federal Wage Hour Laws. Chicago, Illinois. Commerce Clearing House, Inc., August 1975, p. 3.

12. Goldner, op. cit., p. 53.

13. Op. cit., pp. 233-234, Conmerce Clearing House.

14. Goldner, op. cit., p. 53. 
15. $0^{\prime}$ Connor, C. M. "Late Shift Employment in Manufacturing Industries." Month1y Labor Review, November 1970, BLS, U.S. Department of Labor.

16. "Area Wage Surveys, Selected Metropolitan Areas 1970-1971." Bulletin 1685-91, BLS, U.S. Department of Labor, 1972, U.S. GPO. 


DEPARTMENT OF

HEALTH. EDUCATION, AND WELFARE

PUBLIC HEALTH SERVICE

CENTER FOR OISEASE CONTROL

NATIONAL INSTITUTE FDR QCCUPATIONAL SAEETY ANO HEALTH ROBEAT A. TAFT LSEORATOKRIES

4876 COLUMBIA PARKWAY, CINCINNATI, OHIO A5226

POSTACE ANO FESS PALU

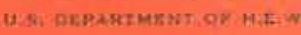

HEW 359

OFFICIAL BUSINESS

PENALTY FOR PRIVATE USE: $\$ 300$ 